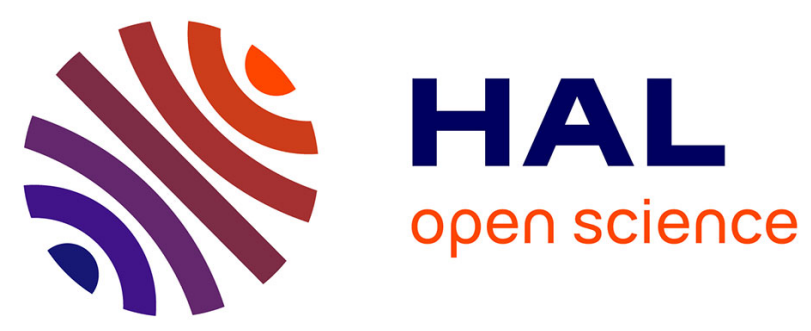

\title{
Diverse cuticular remains in Cambrian (Series 2) SSF assemblages from China and the pioneer metazoan colonization of offshore environments
}

Lei Zhang, Shan Chang, Can Chen, Mats E Eriksson, Qinglai Feng, Michael Steiner, Maliha Zareen Khan, Jean Vannier, Marie-Béatrice Forel, Sébastien Clausen

\section{To cite this version:}

Lei Zhang, Shan Chang, Can Chen, Mats E Eriksson, Qinglai Feng, et al.. Diverse cuticular remains in Cambrian (Series 2) SSF assemblages from China and the pioneer metazoan colonization of offshore environments. Palaeogeography, Palaeoclimatology, Palaeoecology, 2020, 10.1016/j.palaeo.2020.110192 . hal-03098237

\section{HAL Id: hal-03098237 https://hal.science/hal-03098237}

Submitted on 5 Jan 2021

HAL is a multi-disciplinary open access archive for the deposit and dissemination of scientific research documents, whether they are published or not. The documents may come from teaching and research institutions in France or abroad, or from public or private research centers.
L'archive ouverte pluridisciplinaire HAL, est destinée au dépôt et à la diffusion de documents scientifiques de niveau recherche, publiés ou non, émanant des établissements d'enseignement et de recherche français ou étrangers, des laboratoires publics ou privés. 


\title{
Diverse cuticular remains in Cambrian (Series 2) SSF assemblages from China and the pioneer metazoan colonization of offshore environments
}

\author{
Lei Zhang $^{\mathrm{a}, \mathrm{b}}$, Shan Chang ${ }^{\mathrm{c}}$, Can Chen ${ }^{\mathrm{a}, \mathrm{b}}$, Mats E. Eriksson ${ }^{\mathrm{d}}$, Qinglai Feng ${ }^{\mathrm{a}, \mathrm{b}, *}$, Michael Steiner $^{\mathrm{e}}$, \\ Maliha Zareen Khan ${ }^{\mathrm{b}}$, Jean Vannier ${ }^{\mathrm{f}}$, Marie-Béatrice Forel ${ }^{\mathrm{g}}$, Sébastien Clausen ${ }^{\mathrm{h}}$ \\ a School of Earth Sciences, China University of Geosciences (Wuhan), Wuhan, China \\ b State Key Laboratory of Geological Processes and Mineral Resources, China University of Geosciences (Wuhan), Wuhan, Hubei 430074, China \\ c College of Urban and Environmental Sciences, Hubei Normal University. Huangshi 435002, China \\ d Department of Geology, Lund University, Sölvegatan 12, Lund 223 62, Sweden \\ e Department of Earth Sciences, Freie Universität Berlin, Malteserstrasse 74-100, Haus D, Berlin 12249, Germany \\ ${ }^{\mathrm{f}}$ Université de Lyon, Université Lyon 1, ENS de Lyon, CNRS, UMR 5276 Laboratoire de Géologie de Lyon: Terre, Planètes, Environnement, Bâtiment Géode; 2, rue Raphaël Dubois, Villeurbanne \\ F-69622, France \\ g Centre de Recherche en Paléontologie - Paris, UMR7207, MNHN-CNRS-Sorbonne Université; Muséum national d'Histoire naturelle; 8 rue Buffon (CP38), Paris 75005, France \\ ${ }^{\mathrm{h}}$ Univ. Lille, CNRS, UMR 8198 - Evo-Eco-Paleo, Lille F-59000, France
}

\section{A R T I C L E I N F O}

\section{Keywords}

'Orsten'-type

Lagerstätte

micro-ornamentation

cuticle

Shuijingtuo Formation

\begin{abstract}
A B S T R A C T
Our understanding of the early Cambrian bioradiation is largely driven by the contrasting information obtained from small skeletal fossils (SSF) and various types of exceptionally preserved fossils from different parts of the world. In this study, a new 'Orsten'-type fossil Lagerstätte is reported from the Cambrian Series 2 upper Shuijingtuo Formation in the eastern Three Gorges area, South China. The Shuijingtuo Formation yielded a range of microscopic fragments of metazoan cuticles as well as fragments of possible epithelial tissue. Seventeen different types of micro-ornamentation patterns are recognized on the surface of these cuticular fragments. Based on comparisons with fossil organisms recorded from coeval strata elsewhere, as well as extant relatives, possible affinities with arthropods, palaeoscolecids, acrotretid brachiopods and mollusks are discussed. This 'Orsten'-type fossil assemblage was deposited in offshore environments, and the lack of evidence for long-distance transportation indicates that a highly diverse fauna was present in, or very close to, the relatively deep shelf settings in the Three Gorges area during the early Cambrian (Series 2, Stage 3). The invasion of metazoans into deeper, offshore environments could have closely followed, or even been coeval, with their radiation in relatively shallow water settings. Thus, albeit highly fragmented, such cuticular fossils can aid in providing a more complete picture of the Cambrian bioradiation.
\end{abstract}

\section{Introduction}

The well-preserved 'Orsten'-type fossils are generally preserved in three-dimensions by secondary phosphatization, do not exceed $2 \mathrm{~mm}$ in size, and render fine anatomical details (Walossek, 1998; Maas et al., 2006). Although their original organic compounds (e.g. chitin, collagen), and most of their inner tissues and ultrastructure (e.g. layers, Crowe et al., 1970) fossils have been lost through decay and diagenetic processes, they retain exceptionally well-preserved details of their external anatomy and micro-ornamentation (e.g. polygonal patterns, Stankiewicz and Briggs, 2001; Butterfield, 2008; Butterfield and Harvey, 2012).

The first 'Orsten'-type fauna was discovered by Klaus J. Müller (see Maas et al., 2006), from limestone nodules of the Alum Shale Formation of Sweden. In the 1980s and 1990s, studies of 'Orsten'-type fossils mainly focused on arthropods

\footnotetext{
* Corresponding author.

E-mail address: qinglaifeng@cug.edu.cn (Q. Feng)
} 
(especially crustaceans, Maas et al., 2006), allowing accurate reconstruction of the 3D-morphology and developmental stages of numerous Cambrian meiobenthic species (see discussion in Maas et al., 2006).

Since the mid-1990s, 'Orsten'-type preservations have been continuously documented globally, and their age has been further expanded to include the early Ordovician, lower Cambrian, and even the Ediacaran (Zhang and Pratt, 1994; Walossek, 1999; Dong et al., 2005a, 2005b; Maas et al., 2006; Liu and Zhang, 2017). With the discovery of fossil metazoan embryos from the Doushantuo and Kuanchuanpu formations of China, embryology became a new topic in palaeontology (Bengtson and Yu, 1997; Bailey et al., 2007; Cohen et al., 2009; Huldtgren et al., 2011; Cunningham et al., 2012; Yin and Zhu, 2012; Zhang et al., 2014; Yin et al., 2018).

In the 21th century a series of new discoveries have been made which bracket the critical time interval of the Cambrian bioradiation event (Waloszek, 2003; Dong et al., 2005a, 2005b; Maas et al., 2006; Zhang et al., 2010). For example, Zhang et al. (2007); Zhang and Pratt (2012) reported the oldest crown crustaceans and other panarthropod fossils of the Cambrian Epoch 2 in Yunnan Province, South China. Equally important are the phosphatic fossils reported from the Kuanchuanpu Formation in southern Shaanxi Province, China (e.g. Zhang et al., 2007, 2010, 2015; Han et al., 2017). The 535-million-year-old Kuanchuanpu assemblages contain abundant animal remains with putative cnidarian affinities (Wang et al., 2019, 2020; Shao et al., 2018) and diverse scalidophorans (Liu et al., 2014a; Steiner et al., 2014; Zhang et al., 2015; Shao et al., 2016, 2019; Han et al., 2017; Wang et al., 2019, 2020). These have, in addition to the Burgess Shale-type fossils, significantly broadened our understanding of the Cambrian bioradiation.

Based on perceived differences in style of preservation, the 'Orsten'-Lagerstätten have been further sub-divided into an 'Orsten'-type preservation sensu stricto and sensu lato (Maas et al., 2006; or 'Orsten'-type and Doushantuo-type preservations, see Butterfield, 2003; Xiao et al., 2019; Bottjer et al., 2019). The majority of 'Orsten'-type fossils sensu stricto was obtained from Cambrian limestone nodules interbedded with rich black shales. By contrast, the 'Orsten'-type fossils sensu lato were mostly found from Ediacaran to earliest Cambrian phosphatic rocks (Xiao and Knoll, 1999; Chen, 2009), phosphatic limestone, dolostones (Bengtson and Yu, 1997; Steiner et al., 2004, 2014) or cherts (Hua et al., 2005). As the studies progressed, the difference between the two types of preservation became less distinct (Maas et al., 2006; Han et al., 2017). In addition, the vertical distribution and quality of preservation of 'Orsten'-type and Doushantuo-type fossils turned out to be roughly similar (Dornbos, 2011). Therefore, Maas et al. (2006) suggested that they should all united within a single category, the 'Orsten'-type fossils, defined by their size range and secondary phosphatization, irrespective of their age or host rock lithology (Maas et al., 2006).

Putative embryos have previously been reported from the Shuijingtuo Formation in the eastern Three Gorges area, South China (Broce et al., 2014). 'Orsten'-type fossils described here have been recovered from calcareous nodules of the upper Shuijingtuo Formation, in the same area. These assemblages consist of a wide variety of microscopic fragments showing highly diverse micro-ornamentation structures, as well as arthropod compound eyes, limbs, trunks and eggs. The sampled strata belong to the Cambrian Series 2, Stage 3, based on the associated trilobites and SSF biostratigraphy (Zhang et al., 2020), and thus contemporaneous with the Chengjiang
Biota and the 'Orsten'-type crustaceans from the Yu'anshan Formation in Yunnan Province (Zhang et al., 2007, 2010; Zhang and Pratt, 2012). Seventeen different micro-ornamentation patterns are recognized on the surface of these cuticular fragments. Some of them are tentatively assigned to specific animal groups known from elsewhere in the Cambrian and other time periods, allowing a preliminary estimate of the diversity of the communities. Compared to complete specimens, which usually provide diagnostic features (e.g. Zhang et al., 2007), fragmented specimens are often neglected by scientists working on 'Orsten'-type fossils (but see also Castellani et al., 2012). However, recent studies have demonstrated their importance to formulate hypotheses on the origin of moulting (Wang et al., 2019) and the relationships between epidermis and cuticle (Wang et al., 2020). Thus, although difficult to unambiguously attribute to specific taxa, these materials may provide new insights to the early evolution of the metazoans, as well as the offshore colonization by early animals during the Cambrian Bioradiation (Li et al., 2007; Fu et al., 2019).

\section{Geological setting}

All fossils reported here were collected from the Qiaojiaping section which is located in the eastern Three Gorges area, Hubei Province, China. During the early Cambrian, the South China Craton was an isolated microcontinent located at mid-northern latitudes, with the Yangtze Block in the northwest and Cathaysia Block in the southeast (modern coordinates, Fig. 1A; Li et al., 2008). The two blocks were separated by the deep-water Jiangnan ocean basin. The Three Gorges area was located in median position within the Yangtze Platform, which developed as a southwest-northeast epeiric carbonate platform during early Cambrian times (Fig. 1B, Wang and Li, 2003). The studied eastern Three Gorges area has recently been interpreted as recording transitions from carbonate epicontinental platforms and isolated carbonate platforms developed on palaeohighs (uplifts) to deeper intra-platform depressions or basins (Chen et al., 2018). According to this model, the eastern Three Gorges area records more precisely a transition from nearshore to clastic intra-platform basin.

At the Qiaojiaping section, the lower Cambrian succession includes, in stratigraphical order, the upper Yanjiahe, Shuijingtuo and Shipai formations (Fig. 1C). The upper Yanjiahe Formation consists of clastic dolostone interbedded with black shales. Disconformably overlying the Yanjiahe Formation, the Shuijingtuo Formation (ca. 46 m thick) can be subdivided into four beds, in ascending order: (i) Bed 1 (7.2 m thick) dominated by medium-bedded black shales containing abundant limestone nodules and intercalations of black limestone beds; (ii) Bed 2 (25.7 $\mathrm{m}$ thick) is composed of medium-bedded black marls; (iii) Bed 3 (3.5 m thick) is composed of thin-bedded, carbonaceous black shales containing limestone nodules; (iv) Bed 4 (10 m thick) is composed of thick-bedded muddy limestones intercalated with thin-bedded black marls that pass laterally into interbedded grayish-black to purple muddy shales (Zhang et al., 2018a). The overlying Shipai Formation at the Qiaojiaping section is dominated by mudstone interbedded with siltstone (see fig. 2 in Chang et al., 2018). The 'Orsten'-type fossil bearing Bed 3 is dominated by planar laminations and lacks cross laminations, which is consistent with deposition just below the storm wave-base. Neither horizontal nor vertical burrows are present in these black shales.

The Yanjiahe Formation most probably ranges from the E-C transition to the Cambrian Stage 2 (Ishikawa et al., 2008; Guo et al., 2014; Ahn and Zhu, 2017; Chang et al., 2019; Steiner et al., 2020). Due to the occurrence of earliest trilobites of the Tsunyidiscus biozone, the Shuijingtuo Formation is 


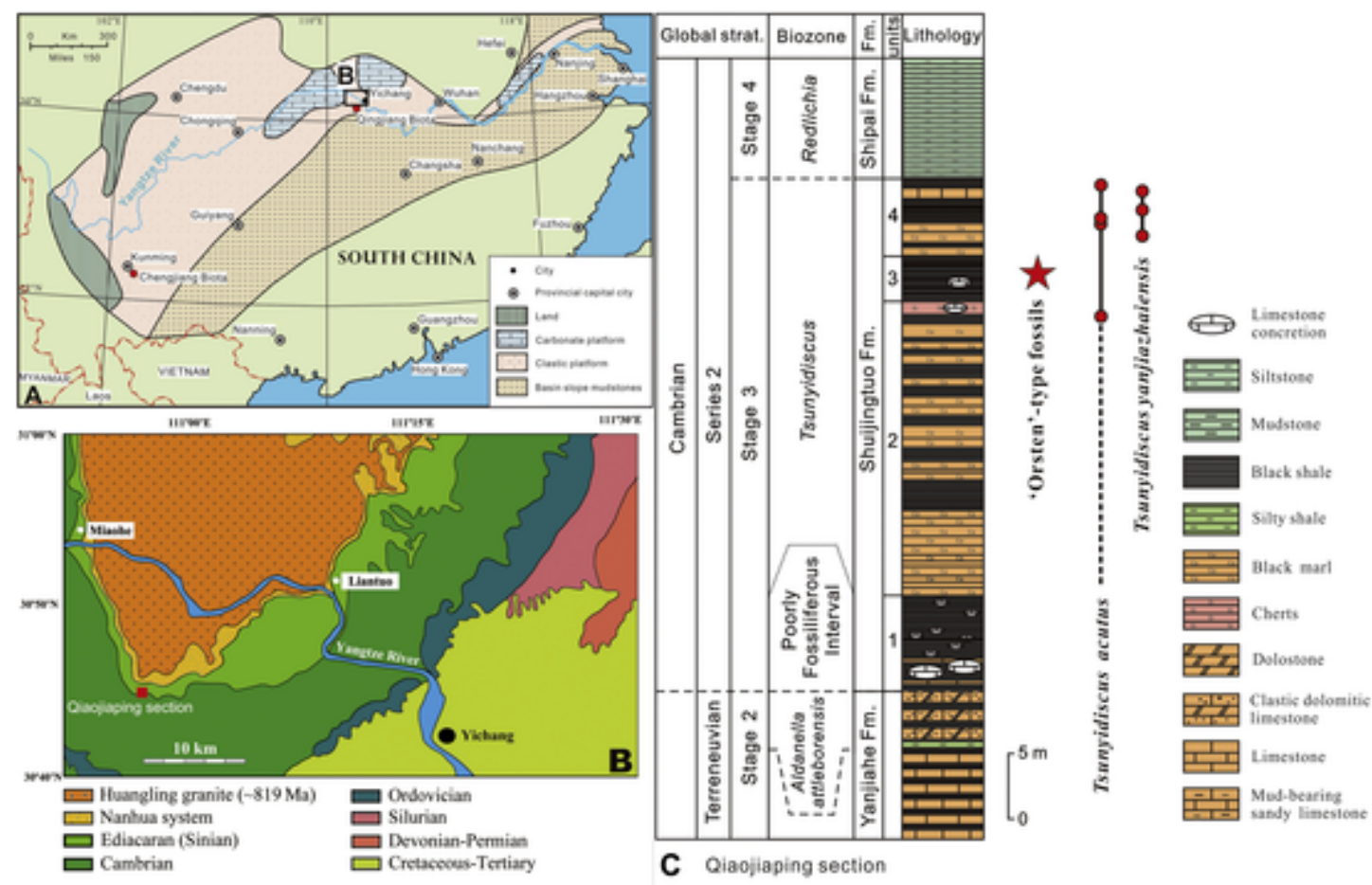

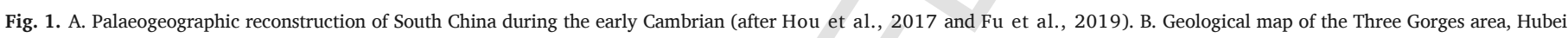
Province (after Guo et al., 2009). C. Position of the 'Orsten'-type fossils discovered from the Shuijingtuo Formation at the Qiaojiaping section.

assigned to the Cambrian Stage 3 (of Series 2) of the provisional stratigraphic framework (Steiner et al., 2007; Dai and Zhang, 2011; Peng et al., 2012). The Shipai Formation mostly spans two trilobite zones, namely the lower Redlichia meitanensis and the upper Palaeolenus lantenoisi zones (Zhang et al., 2015). Thus, the Shipai Formation could be constrained to the Cambrian Stage 4 of the provisional stratigraphic framework (Peng et al., 2012).

\section{Material and methods}

A total of 140 rock samples (each approx. $5 \mathrm{~kg}$ ) were collected from the upper Shuijingtuo Formation in the Three Gorges area and were processed by acid digestion. Limestone samples were broken into pieces of about $100 \mathrm{~cm}^{3}$ and digested into $7 \%$ acetic acid at room temperature. Calcium acetate ( $20 \mathrm{~g}$ per $\mathrm{kg}$ of rocks) was added to the solution to protect fossils from excessive etching. Sample residues were rinsed through $2 \mathrm{~mm}$ and $0.054 \mathrm{~mm}$ meshes and dried at room temperature every two weeks. The fossils were hand-picked under a binocular microscope and selected specimens were mounted on a copper stub using a double-sided adhesive tape and coated with gold or carbon (latter for analytic purposes). The morphology and chemical composition of the fossils were analyzed using a Quanta 200 Scanning Electron Microscope (SEM) equipped with an Energy Dispersive Spectrometer (EDS) and a Field Emission Scanning Electron Microscope (Zeiss Sigma 300 FESEM) at the State Key Laboratory of Geological Process and Mineral Resources (GPMR) at China University of Geosciences (Wuhan), China. All figured specimens are housed in the collection at School of Earth Sciences, China University of Geosciences (Wuhan), Wuhan, P.R. China.

\section{Results}

Acid digestion of limestone nodules from the upper Shuijingtuo Formation yielded abundant SSFs, eodiscoid trilobites, phosphatic fragments and some undetermined fossilized soft tissues, including muscle fibers. The SSFs recovered from the limestone nodules are generally replicated, filled or replaced by calcium phosphate or silicified phosphate, whereas the phosphatic fragments are mainly preserved in the form of calcium phosphate (Yue and Bengtson, 1999). In addition to these phosphatic fragments, other 'Orsten'-type specimens were recovered from the Shuijingtuo Formation, including arthropod trunks (Fig. 2A), putative eggs (Figs. 2B, 2C), exoskeletons of juvenile bivalved arthropods (Fig. 2D), stalked compound eyes with ommatidia (Figs. 2G, 2H; Castellani et al., 2012) and appendages (Fig. 2J; Zhang et al., 2007; Zhai et al., 2019). Similar fragments have also been reported from other 'Orsten'-type fossil Lagerstätten such as that of the Alum Shale Formation of southern Sweden (the Guzhangian Stage of the Cambrian Series 3 and the Furongian; Castellani et al., 2012).

The phosphatic fragments generally display a great variety of surface micro-ornamentations. Some of them show a variable degree of crumpled, twisted and curved features, which might represent intact or decomposed soft parts of organisms rather than biomineralized exoskeletons. Generally, these types of fragments only replicated the micro-ornamentation patterns on one side of the specimens only, whilst arthropod fragments remains show ornamentation patterns on both sides. Most of the ornamented fragments display a consistent uniform pattern on their surface. In total, seventeen $(n=17)$ different types of ornamentation patterns were recognized. Although some of the ornamented patterns identified herein are known from fossil specimens found elsewhere (e.g. Zhang et al., 2007; Butterfield, 2008), most of them have not been reported before. Detailed descriptions of the different patterns are presented below.

\section{Morphological description of the specimens}

All measurements are provided in Table 1. 


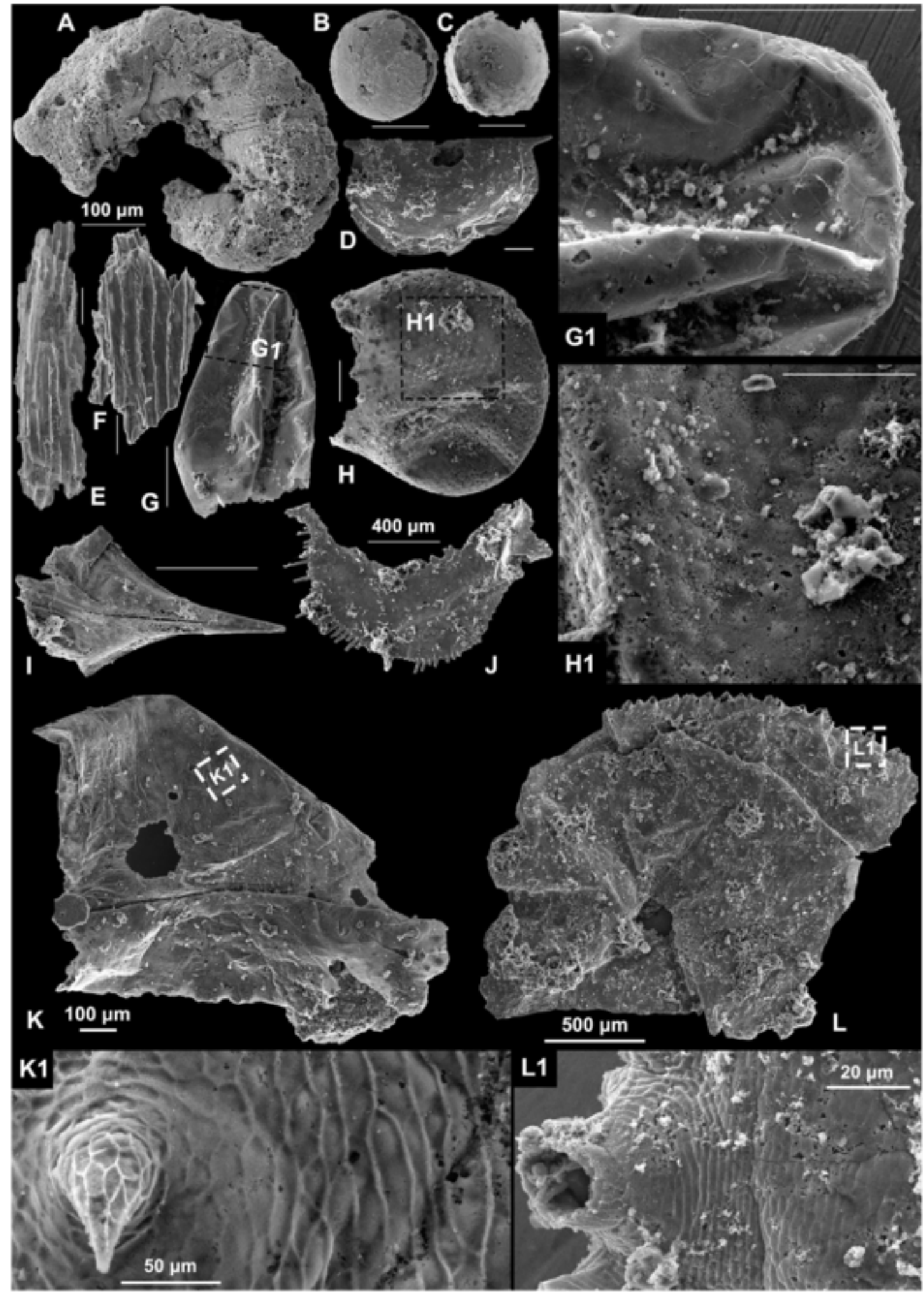

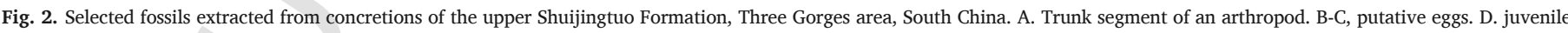

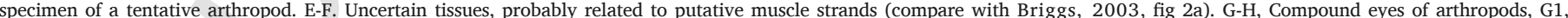

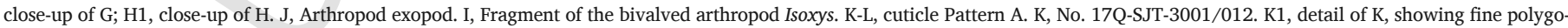

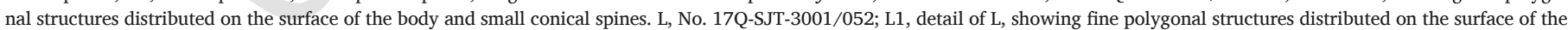
appendages and extended to the top of the spines. Scale bar $100 \mu \mathrm{m}$ for all specimens, unless otherwise specified. 
Table 1

Statistics regarding the studied cuticles, fragmented arthropod, brachiopod moulds and polygons on acritarchs from the Cambrian Series 2 upper Shuijingtuo Formation.

\begin{tabular}{|c|c|c|c|c|c|c|c|c|c|c|c|}
\hline Cuticle Patterns & Specimens & $\begin{array}{l}\text { Abbr. } \\
\text { (see in } \\
\text { Fig. 28) }\end{array}$ & Description of data & & $\begin{array}{l}\text { Number of } \\
\text { measurements }\end{array}$ & $\begin{array}{l}\text { Mean } \\
(\mu \mathrm{m})\end{array}$ & $\begin{array}{l}\text { Median } \\
(\mu \mathrm{m})\end{array}$ & $\begin{array}{l}\text { Min } \\
(\mu \mathrm{m})\end{array}$ & $\begin{array}{l}\text { Max } \\
(\mu \mathrm{m})\end{array}$ & $\begin{array}{l}\text { Standard } \\
\text { deviation }\end{array}$ & $\begin{array}{l}\text { Proportion of } \\
\text { the surface } \\
(\%)^{*}\end{array}$ \\
\hline \multirow[t]{11}{*}{ Pattern A } & $\begin{array}{l}\text { specimen } 1 \\
\text { (17Q- } \\
\text { SJT-3001/052) }\end{array}$ & $\mathrm{A} 1$ & $\begin{array}{l}\text { Maximum } \\
\text { diameter of the } \\
\text { polygons }\end{array}$ & $\mathrm{L}$ & 19 & 14.32 & 11.90 & 8.24 & 35.51 & 6.09 & \multirow[t]{11}{*}{27.37} \\
\hline & $\begin{array}{l}\text { specimen } 2 \\
(17 Q- \\
\text { S-3001-012) }\end{array}$ & A2 & $\begin{array}{l}\text { Maximum } \\
\text { diameter of the } \\
\text { polygons }\end{array}$ & $\mathrm{L}$ & 12 & 43.39 & 29.84 & 8.87 & 140.95 & 37.65 & \\
\hline & & & $\begin{array}{l}\text { Distance } \\
\text { between the } \\
\text { spines }\end{array}$ & D & 6 & 258.93 & 226.80 & 115.69 & 526.73 & 135.76 & \\
\hline & $\begin{array}{l}\text { specimen } 3 \\
\text { (1811Q- } \\
\text { SJT-408/001) }\end{array}$ & A3 & $\begin{array}{l}\text { Maximum } \\
\text { diameter of the } \\
\text { polygons }\end{array}$ & $\mathrm{L}$ & 4 & 126.25 & 126.67 & 85.37 & 166.31 & 30.11 & \\
\hline & $\begin{array}{l}\text { specimen } 4 \\
\text { (17Q-SJT/942) }\end{array}$ & A4 & $\begin{array}{l}\text { Maximum } \\
\text { diameter of the } \\
\text { polygons }\end{array}$ & $\mathrm{L}$ & 28 & 12.75 & 11.67 & 7.8 & 30.01 & 4.86 & \\
\hline & $\begin{array}{l}\text { specimen } 5 \\
\text { (17Q-SJT/942) }\end{array}$ & A5 & $\begin{array}{l}\text { Maximum } \\
\text { diameter of the } \\
\text { polygons }\end{array}$ & $\mathrm{L}$ & 57 & 12.02 & 11.30 & 7.22 & 24.70 & 3.63 & \\
\hline & $\begin{array}{l}\text { specimen } 6 \\
(17 Q- \\
\text { SJT-2000-1/ } \\
013)\end{array}$ & A6 & $\begin{array}{l}\text { Maximum } \\
\text { diameter of the } \\
\text { polygons }\end{array}$ & $\mathrm{L}$ & 73 & 13.84 & 13.73 & 6.69 & 18.93 & 2.73 & \\
\hline & $\begin{array}{l}\text { specimen } 7 \\
\text { (2018Q- } \\
\text { SJT-2001/017) }\end{array}$ & A7 & $\begin{array}{l}\text { Maximum } \\
\text { diameter of the } \\
\text { polygons }\end{array}$ & $\mathrm{L}$ & 57 & 10.46 & 10.40 & 7.72 & 13.40 & 1.44 & \\
\hline & $\begin{array}{l}\text { specimen } 8 \\
\text { (17Q-SJT- } \\
3001 / 058)\end{array}$ & A8 & $\begin{array}{l}\text { Maximum } \\
\text { diameter of the } \\
\text { polygons }\end{array}$ & $\mathrm{L}$ & 74 & 17.02 & 17.24 & 10.69 & 21.67 & 2.42 & \\
\hline & $\begin{array}{l}\text { specimen } 9 \\
\text { (17Q-SJT- } \\
3001 / 223)\end{array}$ & A9 & $\begin{array}{l}\text { Maximum } \\
\text { diameter of the } \\
\text { polvgons }\end{array}$ & $\mathrm{L}$ & 47 & 17.68 & 17.14 & 12.55 & 24.90 & 2.57 & \\
\hline & $\begin{array}{l}\text { specimen } 10 \\
\text { (17Q-SJT-408/ } \\
041)\end{array}$ & $\mathrm{A} 10$ & $\begin{array}{l}\text { Maximum } \\
\text { diameter of the } \\
\text { polygons }\end{array}$ & $\mathrm{L}$ & 47 & 18.61 & 18.26 & 10.22 & 28.11 & 3.67 & \\
\hline
\end{tabular}




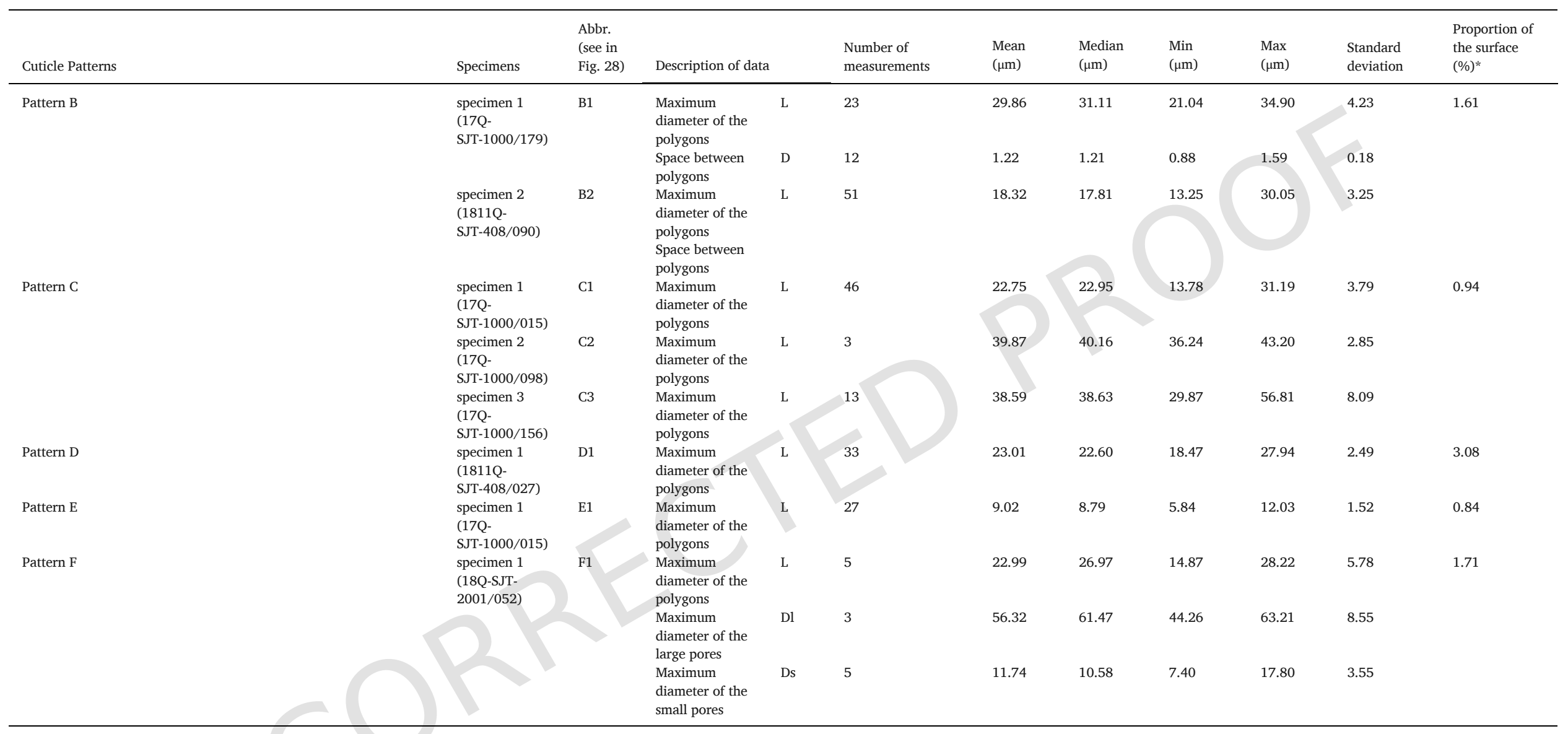




\begin{tabular}{|c|c|c|c|c|c|c|c|c|c|c|c|}
\hline Cuticle Patterns & Specimens & $\begin{array}{l}\text { Abbr. } \\
\text { (see in } \\
\text { Fig. 28) }\end{array}$ & Description of data & & $\begin{array}{l}\text { Number of } \\
\text { measurements }\end{array}$ & $\begin{array}{l}\text { Mean } \\
(\mu \mathrm{m})\end{array}$ & $\begin{array}{l}\text { Median } \\
(\mu \mathrm{m})\end{array}$ & $\begin{array}{l}\text { Min } \\
(\mu \mathrm{m})\end{array}$ & $\begin{array}{l}\operatorname{Max} \\
(\mu \mathrm{m})\end{array}$ & $\begin{array}{l}\text { Standard } \\
\text { deviation }\end{array}$ & $\begin{array}{l}\text { Proportion of } \\
\text { the surface } \\
(\%)^{*}\end{array}$ \\
\hline & $\begin{array}{l}\text { specimen } 2 \\
\text { (18Q-SJT-408/ } \\
081)\end{array}$ & F2 & $\begin{array}{l}\text { Maximum } \\
\text { diameter of the } \\
\text { polygons }\end{array}$ & $\mathrm{L}$ & 10 & 28.39 & 28.58 & 21.81 & 36.16 & 3.98 & \\
\hline Pattern G & $\begin{array}{l}\text { specimen } 1 \\
(1811 Q- \\
\text { SJT-408/060) }\end{array}$ & G1 & $\begin{array}{l}\text { Maximum } \\
\text { diameter of the } \\
\text { polygons }\end{array}$ & $\mathrm{L}$ & 36 & 6.43 & 6.32 & 4.35 & 8.94 & 0.86 & 1.53 \\
\hline \multirow[t]{2}{*}{ Pattern $\mathrm{H}$} & $\begin{array}{l}\text { specimen } 1 \\
\text { (17Q-SJT- } \\
\text { JH1-3001/079) }\end{array}$ & & $\begin{array}{l}\text { Maximum } \\
\text { length of the } \\
\text { swellings }\end{array}$ & $\mathrm{L}$ & 27 & 137.92 & 139.63 & 67.08 & 224.86 & 36.37 & 4.12 \\
\hline & $\begin{array}{l}\text { specimen } 2 \\
(18 Q-S J T- \\
\text { JH29/011) }\end{array}$ & & $\begin{array}{l}\text { Maximum } \\
\text { length of the } \\
\text { swellings }\end{array}$ & $\mathrm{L}$ & 17 & 116.79 & 110.66 & 72.37 & 180.79 & 24.65 & \\
\hline \multirow[t]{2}{*}{ Pattern I } & $\begin{array}{l}\text { specimen } 1 \\
\text { (1811Q- } \\
\text { SJT-408/067) }\end{array}$ & I1 & $\begin{array}{l}\text { Maximum } \\
\text { diameter of the } \\
\text { polygons }\end{array}$ & $\mathrm{L}$ & 8 & 16.47 & 15.44 & 12.78 & 22.93 & 3.58 & 1.55 \\
\hline & & & $\begin{array}{l}\text { Maximum } \\
\text { diameter of the } \\
\text { knots }\end{array}$ & D & 15 & 5.65 & 5.82 & 4.47 & 6.53 & 0.66 & \\
\hline Pattern J & $\begin{array}{l}\text { Specimen } 1 \\
\text { (18Q-SJT- } \\
2001 / 036)\end{array}$ & $\mathrm{J} 1$ & $\begin{array}{l}\text { Maximum } \\
\text { diameter of the } \\
\text { polygons }\end{array}$ & $\mathrm{L}$ & 56 & 30.85 & 31.38 & 20.30 & 38.79 & 3.91 & 1.70 \\
\hline Pattern K & $\begin{array}{l}\text { Specimen } 1 \\
\text { (18Q-SJT- } \\
\text { JH29/056) }\end{array}$ & & Null & Null & Null & Null & Null & Null & Null & Null & 2.23 \\
\hline Pattern L & $\begin{array}{l}\text { Specimen } 1 \\
\text { (1811Q- } \\
\text { SJT-408/032) }\end{array}$ & & $\begin{array}{l}\text { Maximum } \\
\text { diameter of the } \\
\text { microplates }\end{array}$ & $\mathrm{Lm}$ & 144 & 21.71 & 27.71 & 13.72 & 29.08 & 2.86 & 0.56 \\
\hline \multirow[t]{2}{*}{ Pattern M } & $\begin{array}{l}\text { specimen } 1 \\
(17 Q- \\
\text { SJT-1000/112 }\end{array}$ & M1 & $\begin{array}{l}\text { Maximum } \\
\text { diameter of the } \\
\text { pores }\end{array}$ & $\mathrm{L}$ & 7 & 8.16 & 8.36 & 6.54 & 9.88 & 0.95 & 3.11 \\
\hline & & & $\begin{array}{l}\text { Distance } \\
\text { between the } \\
\text { pores }\end{array}$ & D & 6 & 37.21 & 35.49 & 29.69 & 45.60 & 5.93 & \\
\hline Pattern N & $\begin{array}{l}\text { specimen 1 } \\
(18 Q-S-408 / \\
003)\end{array}$ & & $\begin{array}{l}\text { Distance } \\
\text { between the } \\
\text { terrances }\end{array}$ & Dt & 23 & 24.28 & 24.32 & 19.65 & 29.75 & 2.37 & 8.08 \\
\hline
\end{tabular}




\begin{tabular}{|c|c|c|c|c|c|c|c|c|c|c|c|}
\hline Cuticle Patterns & Specimens & $\begin{array}{l}\text { Abbr. } \\
\text { (see in } \\
\text { Fig. 28) }\end{array}$ & Description of data & & $\begin{array}{l}\text { Number of } \\
\text { measurements }\end{array}$ & $\begin{array}{l}\text { Mean } \\
(\mu \mathrm{m})\end{array}$ & $\begin{array}{l}\text { Median } \\
(\mu \mathrm{m})\end{array}$ & $\begin{array}{l}\text { Min } \\
(\mu \mathrm{m})\end{array}$ & $\begin{array}{l}\operatorname{Max} \\
(\mu \mathrm{m})\end{array}$ & $\begin{array}{l}\text { Standard } \\
\text { deviation }\end{array}$ & $\begin{array}{l}\text { Proportion o } \\
\text { the surface } \\
\text { (\%)* }\end{array}$ \\
\hline & & & $\begin{array}{l}\text { Distance } \\
\text { between the tips }\end{array}$ & Dp & 57 & 36.56 & 36.96 & 22.01 & 51.56 & 6.76 & \\
\hline \multirow[t]{11}{*}{ Pattern $\mathrm{O}$} & $\begin{array}{l}\text { specimen } 1 \\
(17 Q-S J T- \\
3001 / 112)\end{array}$ & O1 & $\begin{array}{l}\text { Maximum } \\
\text { diameter of the } \\
\text { pits }\end{array}$ & $\mathrm{L}$ & 47 & 5.28 & 5.28 & 2.61 & 7.47 & 1.01 & \\
\hline & & & $\begin{array}{l}\text { Distance } \\
\text { between the pits }\end{array}$ & $\mathrm{D}$ & 47 & 6.65 & 6.66 & 3.62 & 8.97 & 1.04 & \\
\hline & & & $\begin{array}{l}\text { Distance } \\
\text { between the pits }\end{array}$ & $\mathrm{D}$ & 63 & 18.85 & 18.65 & 14.13 & 23.44 & 2.43 & \\
\hline & $\begin{array}{l}\text { specimen } 3 \\
\text { (17Q-SJT- } \\
3001 / 197)\end{array}$ & $\mathrm{O} 3$ & $\begin{array}{l}\text { Maximum } \\
\text { diameter of the } \\
\text { pits }\end{array}$ & $\mathrm{L}$ & 115 & 10.65 & 10.38 & 5.67 & 17.08 & 2.50 & \\
\hline & & & $\begin{array}{l}\text { Distance } \\
\text { between the pits }\end{array}$ & $\mathrm{D}$ & 115 & 20.92 & 20.85 & 11.33 & 35.09 & 3.78 & \\
\hline & $\begin{array}{l}\text { specimen } 4 \\
\text { (17Q-SJT- } \\
3001 / 228)\end{array}$ & 04 & $\begin{array}{l}\text { Maximum } \\
\text { diameter of the } \\
\text { pits }\end{array}$ & $\mathrm{L}$ & 60 & 11.10 & 11.17 & 5.78 & 17.54 & 2.28 & \\
\hline & $\begin{array}{l}\text { specimen } 5 \\
(18 Q-S-408 / \\
010-2)\end{array}$ & $\mathrm{O} 5$ & $\begin{array}{l}\text { Maximum } \\
\text { diameter of the } \\
\text { pits }\end{array}$ & $\mathrm{L}$ & 53 & 9.53 & 9.60 & 6.25 & 13.25 & 1.69 & \\
\hline & & & $\begin{array}{l}\text { Distance } \\
\text { between the pits }\end{array}$ & $\mathrm{D}$ & 53 & 23.48 & 24.03 & 14.35 & 30.22 & 4.08 & \\
\hline & $\begin{array}{l}\text { specimen } 6 \\
(18 Q- \\
\text { SJT-2001/038 }\end{array}$ & 06 & $\begin{array}{l}\text { Maximum } \\
\text { diameter of the } \\
\text { pits }\end{array}$ & $\mathrm{L}$ & 73 & 4.71 & 4.70 & 2.86 & 6.10 & 0.62 & \\
\hline & & & $\begin{array}{l}\text { Distance } \\
\text { between the pits }\end{array}$ & $\mathrm{D}$ & 56 & 24.61 & 25.04 & 13.59 & 39.79 & 5.05 & \\
\hline & $\begin{array}{l}\text { Specimen } 7 \\
\text { (17Q-SJT- } \\
3001 / 126)\end{array}$ & 07 & $\begin{array}{l}\text { Maximum } \\
\text { diameter of the } \\
\text { pits }\end{array}$ & $\mathrm{D}$ & 59 & 7.84 & 7.59 & 5.99 & 11.01 & 1.20 & \\
\hline
\end{tabular}




\begin{tabular}{|c|c|c|c|c|c|c|c|c|c|c|c|}
\hline Cuticle Patterns & Specimens & $\begin{array}{l}\text { Abbr. } \\
\text { (see in } \\
\text { Fig. 28) }\end{array}$ & Description of data & & $\begin{array}{l}\text { Number of } \\
\text { measurements }\end{array}$ & $\begin{array}{l}\text { Mean } \\
(\mu \mathrm{m})\end{array}$ & $\begin{array}{l}\text { Median } \\
(\mu \mathrm{m})\end{array}$ & $\begin{array}{l}\text { Min } \\
(\mu \mathrm{m})\end{array}$ & $\begin{array}{l}\operatorname{Max} \\
(\mu \mathrm{m})\end{array}$ & $\begin{array}{l}\text { Standard } \\
\text { deviation }\end{array}$ & $\begin{array}{l}\text { Proportion of } \\
\text { the surface } \\
(\%)^{*}\end{array}$ \\
\hline & & & $\begin{array}{l}\text { Distance } \\
\text { between the pits }\end{array}$ & Ds & 59 & 18.54 & 18.56 & 11.12 & 29.72 & 3.47 & \\
\hline \multirow[t]{8}{*}{ Pattern P } & $\begin{array}{l}\text { Specimen } 1 \\
\text { (1811Q- } \\
\text { SJT-408/038) }\end{array}$ & P1.L & $\begin{array}{l}\text { Maximum } \\
\text { diameter of } \\
\text { larger pores }\end{array}$ & Slp & 7 & 23.47 & 22.64 & 22.01 & 27.10 & 1.68 & 3.78 \\
\hline & & & $\begin{array}{l}\text { Distance } \\
\text { between the } \\
\text { larger pores }\end{array}$ & Dlp & 7 & 150.74 & 154.01 & 100.69 & 184.70 & 27.97 & \\
\hline & & P1.S & $\begin{array}{l}\text { Maximum } \\
\text { diameter of } \\
\text { smaller pores }\end{array}$ & Ssp & 97 & 5.39 & 5.38 & 4.59 & 7.09 & 0.41 & \\
\hline & & & $\begin{array}{l}\text { Distance } \\
\text { between the } \\
\text { larger pores }\end{array}$ & Dsp & 97 & 26.78 & 26.93 & 17.09 & 34.17 & 4.05 & \\
\hline & $\begin{array}{l}\text { Specimen } 2 \\
\text { (18Q-S-408/ } \\
035)\end{array}$ & P2.L & $\begin{array}{l}\text { Maximum } \\
\text { diameter of } \\
\text { larger pores }\end{array}$ & Slp & 10 & 24.16 & 24.15 & 18.72 & 28.01 & 2.65 & \\
\hline & & & $\begin{array}{l}\text { Distance } \\
\text { between the } \\
\text { lager pores }\end{array}$ & Dlp & 10 & 150.00 & 154.31 & $112 . .73$ & 208.72 & 31.38 & \\
\hline & & P2.S & $\begin{array}{l}\text { Maximum } \\
\text { diameter of } \\
\text { smaller pores }\end{array}$ & Ssp & 47 & 7.24 & 7.22 & 6.44 & 8.05 & 0.38 & \\
\hline & & & $\begin{array}{l}\text { Distance } \\
\text { between the }\end{array}$ & Dsp & 47 & 25.79 & 25.89 & 20.19 & 30.95 & 2.40 & \\
\hline \multirow[t]{4}{*}{ Pattern Q } & $\begin{array}{l}\text { Specimen } 1 \\
\text { (2018Q-SJT- } \\
2001 / 004)\end{array}$ & Q1 & $\begin{array}{l}\text { Maximum } \\
\text { diameter of the } \\
\text { nodes }\end{array}$ & $\mathrm{L}$ & 79 & 9.65 & 7.75 & 4.68 & 6.28 & 4.92 & 4.54 \\
\hline & & & & $\mathrm{w}$ & 79 & 5.34 & 5.31 & 4.40 & 14.42 & 0.46 & \\
\hline & $\begin{array}{l}\text { Specimen } 2 \\
(17 Q-S-1 / \\
1088)\end{array}$ & Q2 & $\begin{array}{l}\text { Maximum } \\
\text { diameter of the } \\
\text { nodes }\end{array}$ & $\mathrm{L}$ & 99 & 7.41 & 6.85 & 4.19 & 19.41 & 2.22 & \\
\hline & & & & w & 99 & 4.38 & 4.38 & 3.03 & 5.70 & 0.55 & \\
\hline
\end{tabular}




\begin{tabular}{|c|c|c|c|c|c|c|c|c|c|c|c|}
\hline Cuticle Patterns & Specimens & $\begin{array}{l}\text { Abbr. } \\
\text { (see in } \\
\text { Fig. 28) }\end{array}$ & Description of data & & $\begin{array}{l}\text { Number of } \\
\text { measurements }\end{array}$ & $\begin{array}{l}\text { Mean } \\
(\mu \mathrm{m})\end{array}$ & $\begin{array}{l}\text { Median } \\
(\mu \mathrm{m})\end{array}$ & $\begin{array}{l}\operatorname{Min} \\
(\mu \mathrm{m})\end{array}$ & $\begin{array}{l}\text { Max } \\
(\mu \mathrm{m})\end{array}$ & $\begin{array}{l}\text { Standard } \\
\text { deviation }\end{array}$ & $\begin{array}{l}\text { Proportion of } \\
\text { the surface } \\
(\%)^{*}\end{array}$ \\
\hline \multirow[t]{2}{*}{$\begin{array}{l}\text { Eyes of the eodiscoid trilobites } \\
\text { (this study) }\end{array}$} & $\begin{array}{l}\text { Specimen } 1 \\
\text { (1906CK-SP- } \\
\text { /006) }\end{array}$ & TRI1 & $\begin{array}{l}\text { Maximum } \\
\text { diameter of } \\
\text { ommatidia of a } \\
\text { compound eye }\end{array}$ & $\mathrm{L}$ & 25 & 33.28 & 33.49 & 28.22 & 37.59 & 2.53 & \\
\hline & $\begin{array}{l}\text { Specimen } 2 \\
\text { (1906CK-SP- } \\
\text { /009) }\end{array}$ & TRI2 & $\begin{array}{l}\text { Maximum } \\
\text { diameter of } \\
\text { ommatidia of a } \\
\text { compound eye }\end{array}$ & $\mathrm{L}$ & 27 & 24.99 & 24.64 & 22.28 & 29.43 & 1.87 & \\
\hline \multirow[t]{3}{*}{$\begin{array}{l}\text { Compound eyes } \\
\text { (arthropod, this study) }\end{array}$} & $\begin{array}{l}\text { Specimen } 1 \\
\text { (1811Q- } \\
\text { SJT-408/018) }\end{array}$ & ART1 & $\begin{array}{l}\text { Maximum } \\
\text { diameter of the } \\
\text { polygons }\end{array}$ & $\mathrm{L}$ & 12 & 19.53 & 19.83 & 16.47 & 21.89 & 1.72 & \\
\hline & $\begin{array}{l}\text { Specimen } 2 \\
(17 Q-S J T- \\
/ 3001)\end{array}$ & ART2 & $\begin{array}{l}\text { Maximum } \\
\text { diameter of the } \\
\text { polygons }\end{array}$ & $\mathrm{L}$ & 30 & 21.02 & 21.13 & 16.91 & 24.38 & 1.80 & \\
\hline & $\begin{array}{l}\text { Specimen } 3 \\
\text { (17Q-SJT- } \\
3001 / 171)\end{array}$ & ART3 & $\begin{array}{l}\text { Maximum } \\
\text { diameter of the } \\
\text { polygons }\end{array}$ & $\mathrm{L}$ & 13 & 21.08 & 20.31 & 16.02 & 26.41 & 2.9 & \\
\hline \multirow[t]{2}{*}{$\begin{array}{l}\text { Tsunyidiscus acutus } \\
\text { (eodiscoid Trilobites, this study) }\end{array}$} & $\begin{array}{l}\text { specimen } 1 \\
(19 \mathrm{CK}-\mathrm{SJT} / \\
023)\end{array}$ & TSU1 & $\begin{array}{l}\text { Maximum } \\
\text { diameter of the } \\
\text { polygons }\end{array}$ & $\mathrm{L}$ & 25 & 12.12 & 11.94 & 8.21 & 15.55 & 1.85 & \\
\hline & & & $\begin{array}{l}\text { Distance } \\
\text { between spines }\end{array}$ & D & 58 & 65.78 & 65.26 & 40.61 & 106.16 & 12.74 & \\
\hline \multirow[t]{3}{*}{$\begin{array}{l}\text { Hubeidiscus orientalis } \\
\text { (eodiscoid Trilobites, this study) }\end{array}$} & $\begin{array}{l}\text { Specimen } 1 \\
(1906 \mathrm{CK}-\mathrm{SP}- \\
\text { /014) }\end{array}$ & HUB1 & $\begin{array}{l}\text { Maximum } \\
\text { diameter of the } \\
\text { polygons }\end{array}$ & $v$ & 61 & 12.08 & 11.89 & 8.76 & 16.78 & 1.87 & \\
\hline & $\begin{array}{l}\text { Specimen } 2 \\
(1906 \mathrm{CK}-\mathrm{SP}- \\
/ 026)\end{array}$ & HUB2 & $\begin{array}{l}\text { Maximum } \\
\text { diameter of the } \\
\text { polygons }\end{array}$ & $\mathrm{L}$ & 71 & 13.77 & 13.77 & 10.11 & 19.45 & 1.80 & \\
\hline & $\begin{array}{l}\text { Specimen } 3 \\
(1906 \text { CK-SP- } \\
\text { /020) }\end{array}$ & HUB3 & $\begin{array}{l}\text { Maximum } \\
\text { diameter of the } \\
\text { polygons }\end{array}$ & $\mathrm{L}$ & 62 & 12.72 & 12.23 & 9.89 & 19.51 & 1.84 & \\
\hline \multirow[t]{2}{*}{$\begin{array}{l}\text { Liangshanella sp. } \\
\text { (bradoriida, this study) }\end{array}$} & $\begin{array}{l}\text { Specimen } 1 \\
\text { (1906CK-SP- } \\
\text { /014) }\end{array}$ & LIA1 & $\begin{array}{l}\text { Maximum } \\
\text { diameter of the } \\
\text { polygons }\end{array}$ & $\mathrm{L}$ & 25 & 14.02 & 13.74 & 10.18 & 16.39 & 1.45 & \\
\hline & . & LIA1 & $\begin{array}{l}\text { Maximum } \\
\text { diameter of the } \\
\text { pits }\end{array}$ & Dp & 46 & 11.39 & 11.53 & 8.25 & 13.98 & 1.51 & \\
\hline
\end{tabular}




\begin{tabular}{|c|c|c|c|c|c|c|c|c|c|c|c|}
\hline Cuticle Patterns & Specimens & $\begin{array}{l}\text { Abbr. } \\
\text { (see in } \\
\text { Fig. 28) }\end{array}$ & Description of data & & $\begin{array}{l}\text { Number of } \\
\text { measurements }\end{array}$ & $\begin{array}{l}\text { Mean } \\
(\mu \mathrm{m})\end{array}$ & $\begin{array}{l}\text { Median } \\
(\mu \mathrm{m})\end{array}$ & $\begin{array}{l}\text { Min } \\
(\mu \mathrm{m})\end{array}$ & $\begin{array}{l}\text { Max } \\
(\mu \mathrm{m})\end{array}$ & $\begin{array}{l}\text { Standard } \\
\text { deviation }\end{array}$ & $\begin{array}{l}\text { Proportion of } \\
\text { the surface } \\
(\%)^{*}\end{array}$ \\
\hline & & & $\begin{array}{l}\text { Distances of the } \\
\text { pits }\end{array}$ & Ds & 93 & 18.72 & 18.15 & 9.59 & 37.57 & 4.77 & \\
\hline & $\begin{array}{l}\text { Specimen } 2 \\
(1906 \mathrm{CK}-S P- \\
\text { /078) }\end{array}$ & LIA2 & $\begin{array}{l}\text { Maximum } \\
\text { diameter of the } \\
\text { pits }\end{array}$ & Dp & 62 & 9.31 & 9.36 & 5.51 & 13.67 & 1.77 & \\
\hline & & & $\begin{array}{l}\text { Distances of the } \\
\text { pits }\end{array}$ & Ds & 62 & 16.89 & 15.63 & 11.10 & 26.24 & 3.87 & \\
\hline $\begin{array}{l}\text { Eohadrotreta zhenbaensis } \\
\text { (brachiopod, } \\
\text { this study) }\end{array}$ & $\begin{array}{l}\text { Specimen } 1 \\
(1906 \mathrm{CK}-S P- \\
/ 162)\end{array}$ & BRA1 & $\begin{array}{l}\text { Maximum } \\
\text { diameter of the } \\
\text { polygons }\end{array}$ & L & 17 & 22.01 & 22.42 & 17.52 & 26.93 & 2.87 & \\
\hline Scalidophoran cuticular fragments (Wang et al., 2019) & $\begin{array}{l}\text { Specimen } 1 \\
\text { (ELIXX85-120) }\end{array}$ & SCA1 & $\begin{array}{l}\text { Maximum } \\
\text { diameter of the } \\
\text { polygons }\end{array}$ & $\mathrm{L}$ & 91 & 10.11 & 9.88 & 5.12 & 16.71 & 1.86 & \\
\hline
\end{tabular}

* The data shown in this column correspond to Fig. 12. Proportion of the surface means proportion of the surface occupied by each type of ornamentation. Total area of the cuticles is $34.75 \mathrm{~cm}{ }^{2}$.

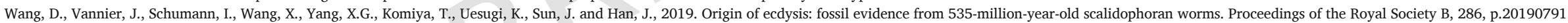


Description. - Variably sized, low relief, palm print-like lattice, sometimes bearing spines on the surface or edge (Figs. 2K, 2L, 3A-3D, 7A-7I); lattices are particularly elongated on specimens shown in Fig. 3A (ca. 12-126 $\mu \mathrm{m}$ for different specimens in Figs. 3A, 3B, 7A, 7B) compared to those of other specimens (ca. $14 \mu \mathrm{m}$ in maximal length for the specimen in Fig. $2 \mathrm{~K}$, ca. $12 \mu \mathrm{m}$ in maximal length for the specimen in Fig. 2L, and ca. $15 \mu \mathrm{m}$ in maximal length for the specimen in Figs. 3C, $7 \mathrm{G}$ ) and the shape of the polygons shows considerable variation over the surface. Similar lattice micro-ornamentation can also be seen on the surface of some appendages (e.g. Fig. 2L). The surface of exceptionally preserved specimens is sometimes wrinkled. Conical spines - covered by the lattice pattern - extend perpendicular to the tips of the short conical spines (ca. $36 \mu \mathrm{m}$ in length of the spines) which are hollow.

Material examined. -2 fragments of arthropod appendages, 15 cuticle fragments.

Remarks. -Although micro-ornamentations vary in shape and size, specimens assigned to Pattern A seem to belong to a single taxon. Because the structures of Pattern A occur on the surface of an appendage (Fig. 2L), these cuticular elements are assigned to arthropods. They might belong to eodiscoid trilobites, bradoriids or bivalved arthropods, because similar lattices can sometimes be observed on the surface of contemporaneous species in South China (e.g. fig. 10 in Zhang, 1987; fig. 3B in Butterfield, 1990; fig. 4 in Haug et al., 2014; fig. 7 in Broda and Zatoń, 2017; Figs. 10-11 in this study).

Occurrence. - Upper Shuijingtuo Formation, Cambrian Series 2, Stage 3.

Description. -Pattern B is characterized by polygons (ca. $24 \mu \mathrm{m}$ in maximal length). Generally, it consists of pentagons and hexagons separated by two parallel walls or lattices (about $1 \mu \mathrm{m}$ thick, Figs. 7J, 7K). The walls are weakly elevated but not flat. Variably sized palm print-like lattices are present in the polygons. Irregular lace-like structures are visible within the polygons, which might represent cell moulds. These laces are sometimes perforated, and may represent taphonomic artefacts rather than original features (Fig. $7 \mathrm{~K}$ ).

Material examined. -2 specimens.

Occurrence. - Upper Shuijingtuo Formation, Cambrian Series 2, Stage 3.

Description. - Fragments with Pattern C ornament are smooth and characterized by relatively large pentagons or hexagons (ca. $40 \mu \mathrm{m}$ in maximal length, Fig. 3G) separated by low relief ridges. One specimen (Fig. $3 \mathrm{H}$ ), which lacks distinct ridges, might be the negative mould of surface structures. They are considered herein as Pattern $\mathrm{C}$ with specific ornamentation defined by the size of the polygons $(40 \mu \mathrm{m}$ in maximal length for Fig. $3 \mathrm{G}$ and $39 \mu \mathrm{m}$ for Fig. $3 \mathrm{H}$ ). One specimen with Pattern $\mathrm{C}$ ornamentation shows numerous circular pits with a diameter of about $1.5 \mu \mathrm{m}$ (Figs. 7M, 7N). The size and morphology of the pits suggest that they might be cell moulds (see Fig. 7N).

Material examined. -2 specimens.

Remarks. - The characteristics of the polygons and ridges remarkably recall those of Pattern A, but the size of the former is much larger. Specimens with Pattern C ornamentation probably belong to arthropods as similar structures can be seen on the carapace of some bivalved arthropods, such as Isoxys and Tuzoia (Fu et al., 2014; Wen et al., 2015).

Occurrence. - Upper Shuijingtuo Formation, Cambrian Series 2, Stage 3.

Description. -Due to incomplete replication, micro-ornamentations are only visible in a small area of a single specimen. Boundaries have no relief. Pattern D is composed of regu- larly distributed polygons (ca. $23 \mu \mathrm{m}$ in maximal length) with indistinct boundaries, resulting in an overall structure with complex polyhedron appearance (Fig. 70). The surface of all polygons is smooth. No finer micro-ornamentation occurs within the polygons.

Material examined. -One specimen.

Remarks. - The only fragment with Pattern D polygonal ornament, preserving a strait linear structure similar to a dorsoventrally compressed hinge line, is interpreted herein as derived from a bivalve arthropod.

Occurrence. - Upper Shuijingtuo Formation, Cambrian Series 2, Stage 3.

Description. - Pattern E is characterized by a network of polygonal walls delimiting convex, almost hemispheric, lenticular surfaces (the polygons and lenticulars are ca. $9 \mu \mathrm{m}$ in width; Fig. 8A). Polygonal walls are very regular, and resemble honeycombs. These lenticular structures are hollow, as can be observed in fractured areas (Fig. 8A). Such a micro-ornament only occurs in a certain area of the specimen and gives room to irregular stripe structures elsewhere (Fig. 3J).

Material examined. -One specimen.

Remarks. - The lenticular structure of this specimen strongly resembles those of the compound eyes of arthropods. However, a clear compound eye structure (e.g. globular or convex shape eyeball, optic stalk, etc, cf. Figs. 2G, 2H) is lacking here.

Occurrence. - Upper Shuijingtuo Formation, Cambrian Series 2, Stage 3.

Description. - Fragments with Pattern F are characterized by subparallel straight ridges separating deep, relatively wide (about 50-100 $\mu \mathrm{m}$ in width) furrows with concave floor. The furrows are covered with small, irregular, sub-polygonal ornament (about $25 \mu \mathrm{m}$ in width; Figs. 8C). Rounded pores are evenly distributed within the furrows. The larger ones (up to $55 \mu \mathrm{m}$ in diameter) are bounded by up to ten rows of deformed polygons/folds forming a variably extended, invagination or collar. Most of the smaller pores (maximal diameter ca. $12 \mu \mathrm{m}$ ) regularly appear adjacent to the large ones, but some are independently scattered on other parts of the cuticle (Figs. 8C).

Material examined. -2 specimens.

Remarks. - The furrows described in Pattern F are comparable to the annuli observed on the cuticle of segmented worms (Zhang and Pratt, 1996). Pores of various size, sometimes with short and inward extended collars, might correspond to partially degraded setae, parapodia or appendages of vermiform fossils (Müller and Hinz-Schallreuter, 1993). The three features (closely spaced annuli, circular hollows and polygonal structures) together suggest that the cuticle remains of Pattern F might be assigned to Palaeoscolecida, an extinct group of scalidophoran worms with a worldwide distribution and well represented in both Burgess Shale- and 'Orsten'-type Lagerstätten (Glaessner, 1979; Hou and Bergström, 1994; Zhang and Pratt, 1996). The precise relationship of the Palaeoscolecida to the priapulids or alternatively the nematomorphs remains under discussion, but it is suggested that their systematic position is within the superphylum Ecdysozoa (moulting invertebrate animals, Ivantsov and Wrona, 2004). Microplates and/or platelets are typical of palaeoscolecids. The platelets were either originally absent, or secondary lost from our specimens. Limited preserved features preclude any further assignment to any palaeoscolecid species.

Occurrence. - Upper Shuijingtuo Formation, Cambrian Series 2, Stage 3.

Description. - Fragments with G Pattern are weakly twisted. Very fine, dense reticulate and irregular ridges (ca. $6.4 \mu \mathrm{m}$ in maximal length of the polygons, Fig. 8D) which are particu- 


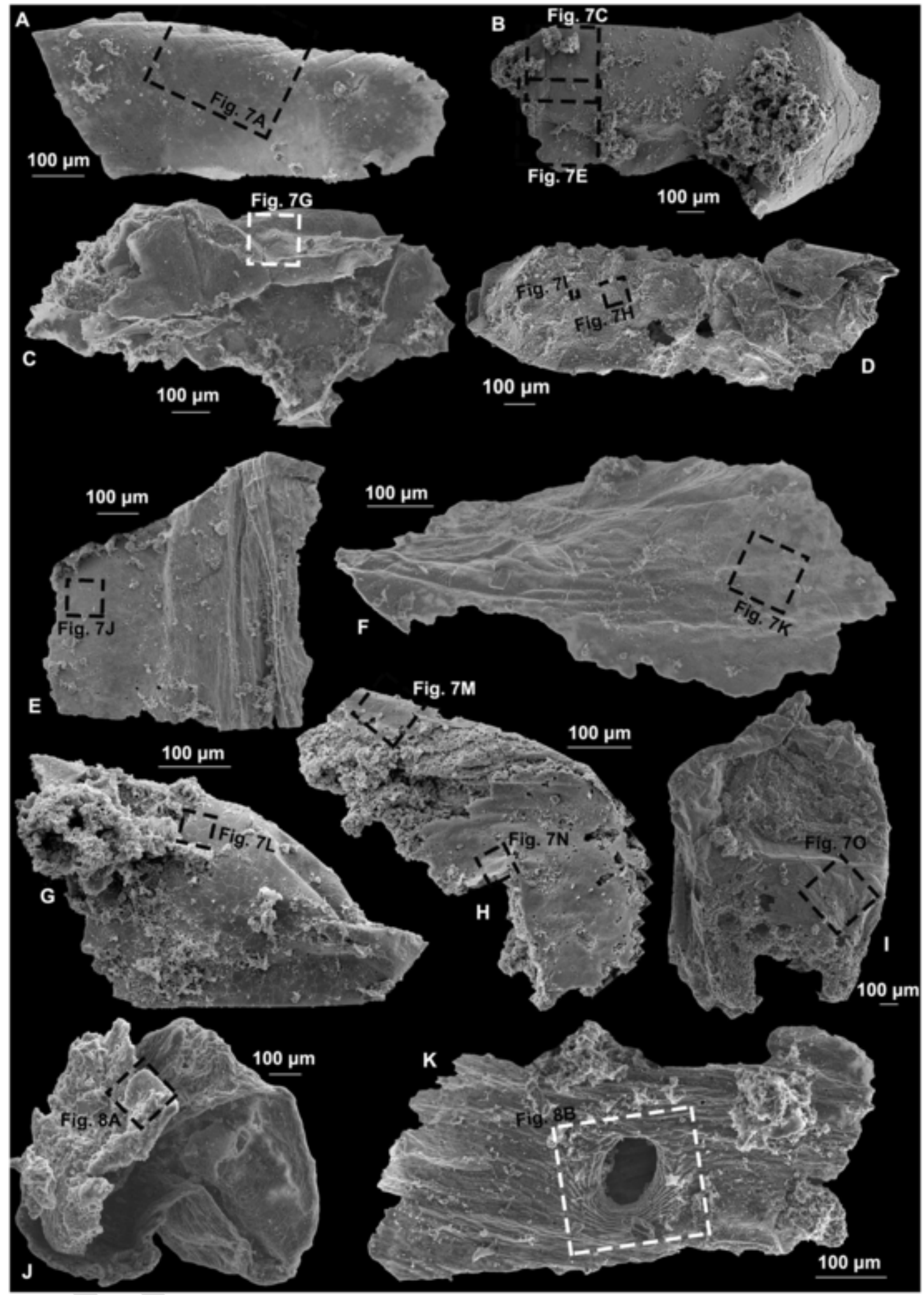

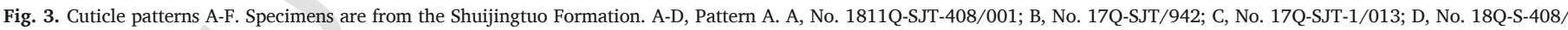

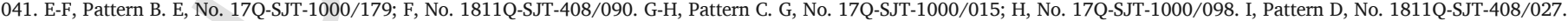
J, Pattern E, No. 17Q-SJT-1000/015. K, Pattern F, No. 18Q-SJT-408/081.

larly visible in some areas (see Fig. 8D). In other areas, it gradually changes into fine strip-like patterns (Fig. 8E). A prominent cone-shaped spine, preserved as a possible steinkern, protrudes from the surface of the cuticle $\quad$ (ca. $\quad 253 \quad \mu \mathrm{m}$ in length, $200 \mu \mathrm{m}$ in basal diameter, Fig. 4B). Whether this spine is hollow or solid cannot be determined since no fracture is present. The surface of the spine is smooth.

Material examined. - One specimen. 
Remarks. - The specimen with ornament Pattern G is a phosphatic steinkern, partly enveloped by a cuticle. The spine differs from those observed in specimens showing an ornament pattern of type A. Although some vermiform ecdysozoans have similar spines and surface patterns (e.g. Zhang et al., 2018b), no accurate assignment to this group is possible.

Occurrence. - Upper Shuijingtuo Formation, Cambrian Series 2, Stage 3.

Description. - Pattern $\mathrm{H}$ consists of an irregular network of narrow (about $2 \mu \mathrm{m}$ ), sharp furrows delimiting polygonal areas. The center of these areas can be flat (Figs. 4E, 8G), perforated by subcircular pores bordered by rounded rims (Fig. 4D), or occupied by a variably developed convex pock, sometimes perforated at its apex (Figs. 4E, 8F).

Material examined. -3 specimens.

Remarks. - Similar pock-marked cuticles have also been found in Small Carbonaceous Fossils (SCFs) from the Burgess Shale and, the early Cambrian Mahto Formation, (Alberta, Canada) and the Kaili Lagerstätte (Guizhou Province, South China) (see figs. 9.1-7 in Butterfield, 2008; fig. 7S in Harvey et al., 2012). On the specimens described by Butterfield (2008, fig. 9), the pock-marks are characterized by a thickened, more or less circular, sometimes lozenge-shaped rim features, similar to the rim observed herein around pores. The perforations may result from the taphonomic process (Butterfield, 2008). The elements described by Butterfield (2008) were interpreted as belonging to a molluscan radula. Indeed some features closely resemble those found in extant aplacophoran molluscs. The pock-marked cuticle is interpreted as having supported multiple biomineralized sclerites/spines in the manner of a modern chiton girdle (Butterfield, 2008). The similar ornament seen in our specimens may belong to a similar radula-like organ as well.

Occurrence. - Upper Shuijingtuo Formation, Cambrian Series 2, Stage 3.

Description. - The lattice of Pattern I is characterized by a network of fine, narrow, straight ridges surrounding flat, irregularly polygonal areas (up to $16.47 \mu \mathrm{m}$ in width; Figs. 4F, 8H). Star-shaped (Fig. $8 \mathrm{H}$ ) to rounded knobs (Fig. $8 \mathrm{H}$ ) are formed at some intersections between ridges. They seem to preferentially occupy multiple-intersections, between more than 4 ridges, triple points generally lacking a knob-structure. The maximal diameter of the knobs is $5.65 \mu \mathrm{m}$. The length of the polygon segment ranges from 8 to $20 \mu \mathrm{m}$.

Material examined. -2 specimens.

Remarks. - Similar structures occur in arthropods such as eodiscoid trilobites (Figs. 4G, 8I, 11) and the bradoriid Kunmingella xiaoyangensis (see Plate 6, fig. 8 in Zhang, 2007). Our cuticle fragments are therefore tentatively interpreted as derived from arthropods.

Occurrence. - Upper Shuijingtuo Formation, Cambrian Series 2, Stage 3.

Description. - A thin, elevated ridge can be observed in the middle of the specimen with Pattern J. Rhombic depressions (ca. $30 \mu \mathrm{m}$ in maximal length) separated by the ridge are present along the external surface of the cuticular fragment; in places, the rhombic structures appear to gradually deform into fish scale-like depressions (Figs. 8J, 8K).

Material examined. - One specimen.

Remarks. - SSFs such as Rhombocorniculum (see figs. 46-48 in Kouchinsky et al., 2013), Mongolitubulus or Rushtonites, have a similar ornamentation pattern and might belong to the spines of hallucigeniid lobopodians (see SCFs described in Caron et al., 2013) or eodiscoid trilobites (Li et al., 2003). However, the ornament in Hallucigenia, Mongolitubulus and
Rushtonites generally displays cone-in-cone structures, which are resulting from the retention of moulted cuticular elements (Caron et al., 2013). Our specimens are also much larger than those described in Caron et al. (2013), but indeed are very similar to the specimens shown in Kouchinsky et al. (2013; figs. 46-48).

Occurrence. - Upper Shuijingtuo Formation, Cambrian Series 2, Stage 3.

Description. - Pattern K is strongly folded, and wrinkled, covered by a fine fishnet-like structure (Fig. 8L). No small-scale ornamented features are visible due to folding, crumpling and poor preservation. However, Pattern K differs from all other ornamented types.

Material examined. -3 specimens.

Occurrence. - Upper Shuijingtuo Formation, Cambrian Series 2, Stage 3.

Description. - The single specimen with Pattern L has two adjacent layers that probably represent the external and internal layer of fossil fragment (Fig. 5A). This pattern consists of irregularly tessellated polygonal elements (microplates; about $22 \mu \mathrm{m}$ in maximal width). The microplates have a concave surface, interpreted herein as the outer surface (Fig. 8M), which is bounded by a smooth to faintly pustulose ridge. The layer beneath is generally smooth. Convex structures can be found on its surface. It might be the prints of polygonal microplates.

Material examined. -One specimen.

Remarks. - The microplates on this specimen resemble the cuticular plates seen on the annuli of ecdysozoans. In particular, similar tessellation can be observed on the trunk of palaeoscolecid worms (Zhang and Pratt, 1996; Ivantsov and Wrona, 2004). The double layer may represent exfoliation of the outer layer of the cuticle (figs. 2.5, 2.6 in Zhang and Pratt, 1996), or most probably the two surfaces of a partially preserved folded and flattened cuticle.

Occurrence. - Upper Shuijingtuo Formation, Cambrian Series 2, Stage 3.

Description. - M-type specimens have a curled shape and show transverse ripples. The $\mathrm{M}$ ornamentation pattern consists of densely packed, irregularly anastomosing (or bifurcating) ripples. Ripples have a regular transverse, rounded shape. Drop-shaped pits, bounded by ripples, are irregularly distributed on the cuticle surface (Fig. $8 \mathrm{~N}$ ). Pits diameter is ca. $8 \mu \mathrm{m}$ and the spacing between the pores is ca. $30-50 \mu \mathrm{m}$.

Material examined. -3 specimens.

Remarks. - Pattern M resembles the ornament found on certain cuticular areas of Yicaris. Yicaris is the earliest crown crustaceans reported from the contemporaneous Yu'anshan Formation (Series 2, Stage 3) in Yunnan Province, South China (Zhang et al., 2007). The legs of the anomalocaridid Cucumericrus decoratus also bear comparable ornament (Hou et al., 2017).

Occurrence. - Upper Shuijingtuo Formation, Cambrian Series 2, Stage 3.

Description. - Fragments with N Pattern are weakly twisted. A ridge line can be observed in at least three specimens, which generally a fold along this line. Pattern $\mathrm{N}$ is characterized by transverse serrate terraces (Figs. 5C, 5D), which are distributed in regular, concentric parallel rows. Small tips occur on the terraces (Fig. 80). The distance between those tips is generally constant ( 16 and $31 \mu \mathrm{m}$ ). The surface between the two adjacent terraces is smooth.

Material examined. -5 specimens.

Remarks. —Pattern N differs from Pattern $\mathrm{M}$ by having more regular transverse stripes. Cuticular terraces are found in a number of arthropod groups in which they have evolved independently (e.g. Schmalfuss, 1978, 1981). The absence of 

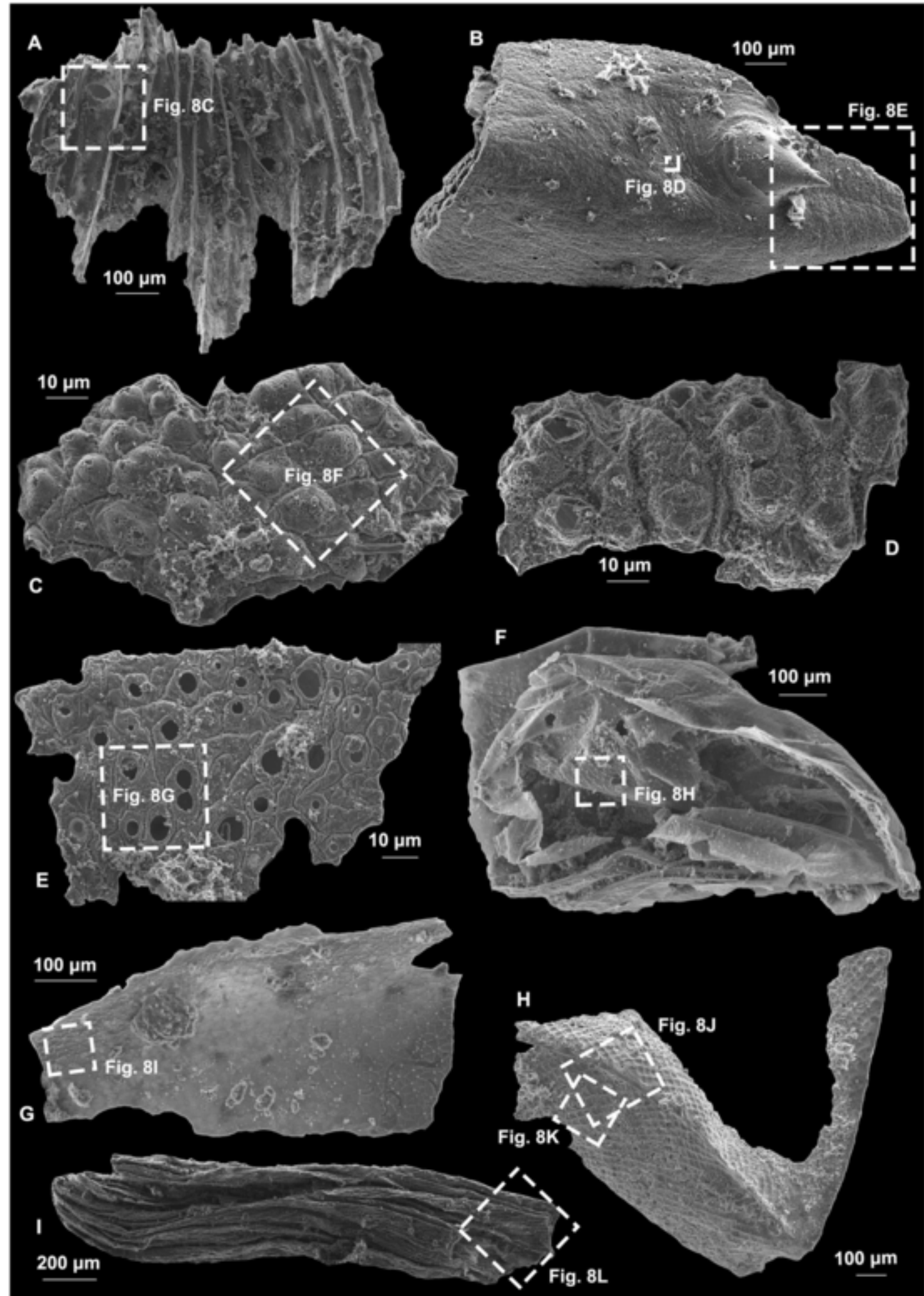

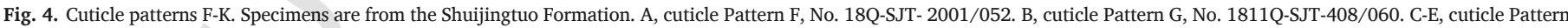

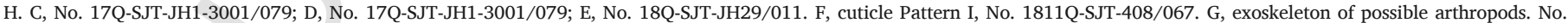
1811Q-SJT-408/047. H, cuticle Pattern J. No. 18Q-SJT- 2001/036. I, cuticle Pattern K, No. 18Q-SJT-JH29/056.

detailed diagnostic features precludes further taxonomic assessment.

Occurrence. - Upper Shuijingtuo Formation, Cambrian Series 2, Stage 3.
Description. -Pattern $\mathrm{O}$ is represented by fragments with numerous pits or trails. This pattern is the most abundant in our fossil material (Fig. 12). Specimens (Figs. 5E-5H) has the overall appearance of an orange peel. Pits have a maximum di- 


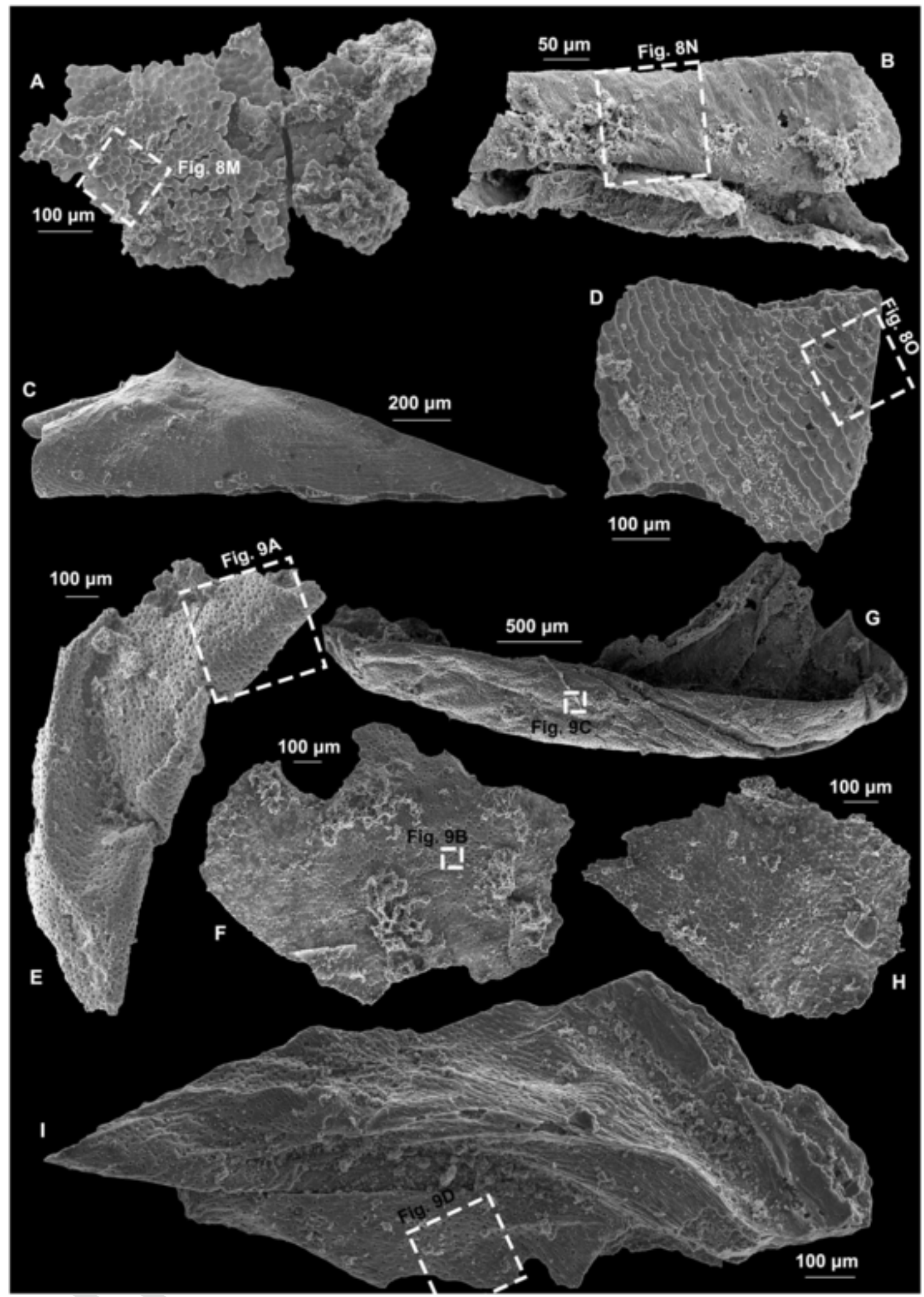

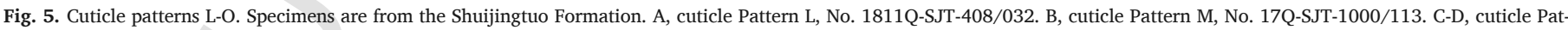

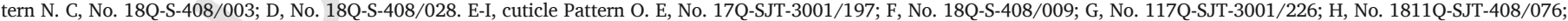
I, No. 18Q-SJT-2001/038.

ameter of ca. $10 \mu \mathrm{m}$ and the distance between adjacent pits is ca. $19 \mu \mathrm{m}$. Some specimens (Figs. 5I, 9D, 9E) have slightly smaller pits (maximal diameter of the pits ca. $5 \mu \mathrm{m}$, distance between the pits ca. $25 \mu \mathrm{m})$ and a smooth interspace; most of the pits on the specimens in Fig. 5I are uniformly inclined (Figs. 9D, $9 \mathrm{E})$. Irregular pits and shallow grooves are also visible on the surface (maximal diameter of the pits ca. $8 \mu \mathrm{m}$, distance between the pits ca. 19 $\mu \mathrm{m}$, Figs. 9F, 9G). 
Material examined. - 19 specimens.

Remarks. - Similar pits and polygons can be observed on the surface of the phosphatic shell of some bradoriids (Liangshanella, Fig. 10). Some of these features have been interpreted as the possible boundaries of epithelial cells that secreted the cuticle (e.g. brachiopods; Zhang et al., 2016a), although a specific taxon is impossible to assign.

Occurrence. - Upper Shuijingtuo Formation, Cambrian Series 2, Stage 3.

Description. - Remains with Pattern P are flat to irregularly folded. Bimodal pits are evenly distributed on the surface of these fragments: the smaller pits are almost isometric, flat, hemispherical and ca. $6 \mu \mathrm{m}$ in diameter (Fig. 9K); the larger ones are more irregular in shape, and more sparsely distributed with a diameter of ca. $24 \mu \mathrm{m}$ (Fig. 9J).

Material examined. -2 specimens.

Remarks. - Comparable features occur in acrotretid brachiopods or hyoliths that have been interpreted as cell boundaries (Zhang et al., 2016b, 2018b). Regular hemispheric pits appear to be closely related to the epithelial cell moulds on some acrotretid brachiopods or hyoliths (Zhang et al., 2016b, 2018b). However, those latter pits are all of the same size (Zhang et al., 2016b, 2018b). Shells of tannuolinid tommotids are penetrated by regular tubules. Regularly distributed pores can be observed in tannuolinids, but they are generally deeper (Skovsted et al., 2014).

Occurrence. - Upper Shuijingtuo Formation, Cambrian Series 2, Stage 3.

Description. - Remains with Pattern Q consists of numerous tightly packed and linearly arranged nodes (Fig. 6F). Nodes have an irregular, polygonal to subcircular shape and a flat top surface. The height of these nodes is relatively uniform with variable lengths (maximal length ca. $9 \mu \mathrm{m}$ ). Some conical, crater-like, higher structures with a central pit sparsely protrude between the nodes (Figs. 9M, 9N). The diameter of these cones is around $15 \mu \mathrm{m}$.

Material examined. -2 specimens.

Remarks. - The Pattern $\mathrm{Q}$ has never been described in any Orsten specimens. It is therefore impossible to attribute it to any known clade.

Occurrence. - Upper Shuijingtuo Formation, Cambrian Series 2, Stage 3.

\section{Discussion}

\subsection{Origin of ornamented fragments?}

Although represented by fragments, these fossil assemblages from the upper Shuijingtuo Formation are remarkable by the diversity of their ornamentation patterns and the quality of their preservation. However, their biological affinities are difficult to determine because $i$ ) most of the micro-ornamentation patterns here have never been described in whole or larger body fossils; ii) trunks, heads or appendages to which these cuticular fragments may have belonged, are missing, and; iii) external ornamentation patterns cannot be used as accurate diagnostic features as shown by extant arthropods from different groups which share comparable cuticular ornament (e.g. polygons, nodes, pits, etc).

Although micro-ornamentation in animals often finds its origin in self-organized processes, it acquired various ecological functions through evolution. The cuticle of many Cambrian and extant ecdysozoans acts as an interface between the body and the surrounding environment and for this reason, plays an important role in several vital functions, such as protection (from physical damage and predators) and locomotion, and also accommodates sensory organs (e.g. infaunal worms;

Brad- bury and Vehrencamp, 1998; Stankiewicz and Briggs, 2001; Yang and Sun, 2006; Neville, 2012; Pérez-de la Fuente et al., 2012; Broda and Zatoń, 2017; Manukyan et al., 2017). Micro-reticulation patterns (polygonal structures) represent one such example. The cuticle is secreted from underlying epithelial cells and, in ecdysozoans (Scalidophora, Nematoida, Panarthropoda), is renewed periodically via ecdysis (Wang et al., 2019, 2020). In many ecdysozoan groups, the external reticulated ornament faithfully replicates the boundaries of the epithelial cells (Zhang and Pratt, 1994; Yang et al., 2019; Wang et al., 2020). Polygonal structures arose independently in many Cambrian animal groups (cuticle sensu lato, such as mollusks, brachiopods and hyoliths (Parkhaev, 2006, 2014; Zhang et al., 2016b, 2018c; Li et al., 2019), which provides little taxonomic specificity. Reticulated patterns also can be found in a variety of non-metazoan organisms, including acritarch vesicles preserved as organic-walled fossils (Xiao and Knoll, 1999; Su et al., 2010; Xiao et al., 2014; Agić et al., 2017). Numerous embryos also have a polygonal pattern due to dividing blastomeres (Yin and Zhu, 2012; Broce et al., 2014). The size of these polygons, whether they correspond to cell boundaries or result from other processes, often varies according to their location on the surface of organisms and/or the ontogenetic stages (e.g. Zhang and Pratt, 1996; Waugh et al., 2009; Zhang et al., 2016b). There is no fundamental differences between the size of polygonal patterns in acritarchs, embryos and the cuticular fragments described herein (Fig. 13, see also Yin and Zhu, 2012; Broce et al., 2014; Agić et al., 2017). The unimodal size distribution of polygonal structures is therefore probably not a practical guide for distinguishing species.

Acritarchs have developed diverse ornamentations such as polygonal structures, spines, microgranulae etc (e.g. Liu et al., 2014a). The ornament of some of the fossils described herein may be compared with that of the large acanthomorphic accritarchs (Xiao and Knoll, 1999; Su et al., 2010; Xiao et al., 2014; Agić et al., 2017). However, i) the large acanthomorphic acritarchs became instinct by the early Cambrian Stage 3 (Yin and Gao, 1995), and; ii) the large acanthomorphic acritarchs fall within the range of a few hundred microns (Xiao and Knoll, 1999; Su et al., 2010; Xiao et al., 2014; Agić et al., 2017), which is much smaller than most of our fossil remains. Similarly, most embryos from the Ediacaran and Cambrian reach a few hundred microns (Yin et al., 2018). The ornamented fragments described herein are therefore interpreted as metazoan cuticles or associated tissues (in particular epithelial). They share numerous common features with ecdysozoans (such as the pavement of epithelial cells, sensory pores, etc), which are recorded from the early Cambrian (Wang et al., 2019, 2020). Moreover, they seem to be dominated by ecdysozoans sensu lato, since micro-reticulated networks and microplates are found in, for example, both arthropods and scalidophorans; e.g. Zhang and Pratt, 1996; Dornbos, 2011; Wang et al., 2019). Possible affinities with arthropods, palaeoscolecid worms (Zhang and Pratt, 1996), acrotretid brachiopods (epithelial cells, Zhang et al., 2016a), mollusks (Butterfield, 2008) are proposed in the systematic section.

The Burgess Shale preservation generally obscures micro-ornamentation (because of compression and diagenesis, Gaines et al., 2012). This is not the case in Orsten-type assemblages in which small organisms or fragments are secondarily phosphatized, leading to exquisite 3D-preservation of mostly cuticularized body-parts (Butler et al., 2015; Liu et al., 2018). Thus, fossil cuticles have great potential to provide important information on the ecology, cellular structure of internal tis- 


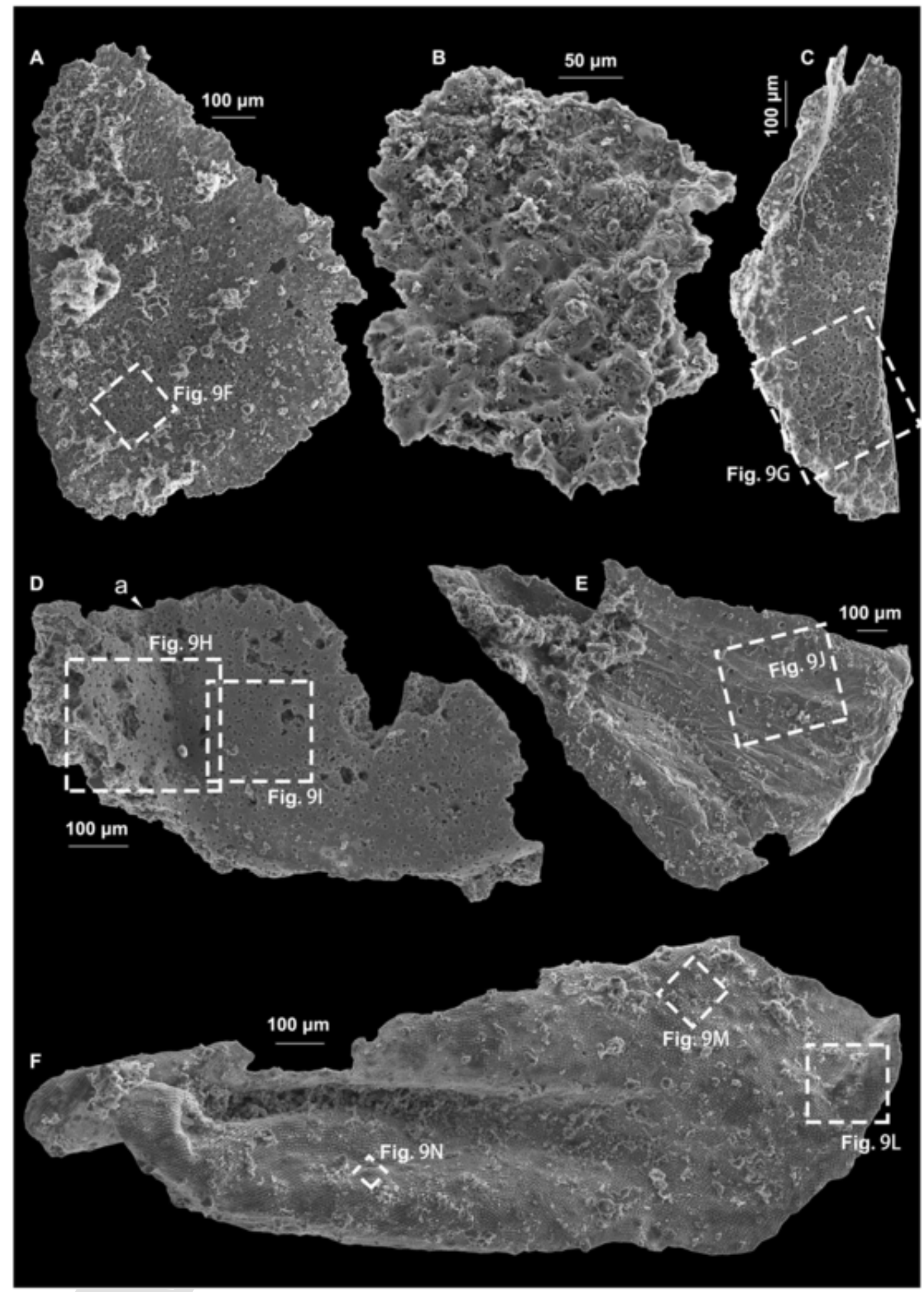

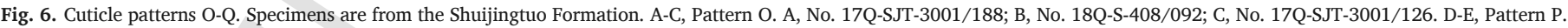
D, No. 18Q-S-408/035; E, No. 1811Q-SJT-408/038. F, Pattern Q, No. 2018Q-SJT/004.

sues and growth mode of ancient animals (Zhang and Pratt, 1996; Castellani et al., 2012). In this context, 'Orsten'-type fossil Lagerstätten have attracted increasing attention because they capture fine details of external features that are rarely preserved in Burgess Shale-type fossils, where the organic cuticles are often replaced by aluminosilicates or iron minerals (Gaines et al., 2012).
The cuticular remains described here reveal a faunal assemblage with a relatively high diversity, probably dominated by ecdysozoans (scalidophorans and panarthropods, Fig. 12, Table 1). However, to which species, genus or suprageneric categories these fragments belong remains uncertain. Yet, the only way to identify these fragments would be to assign them 

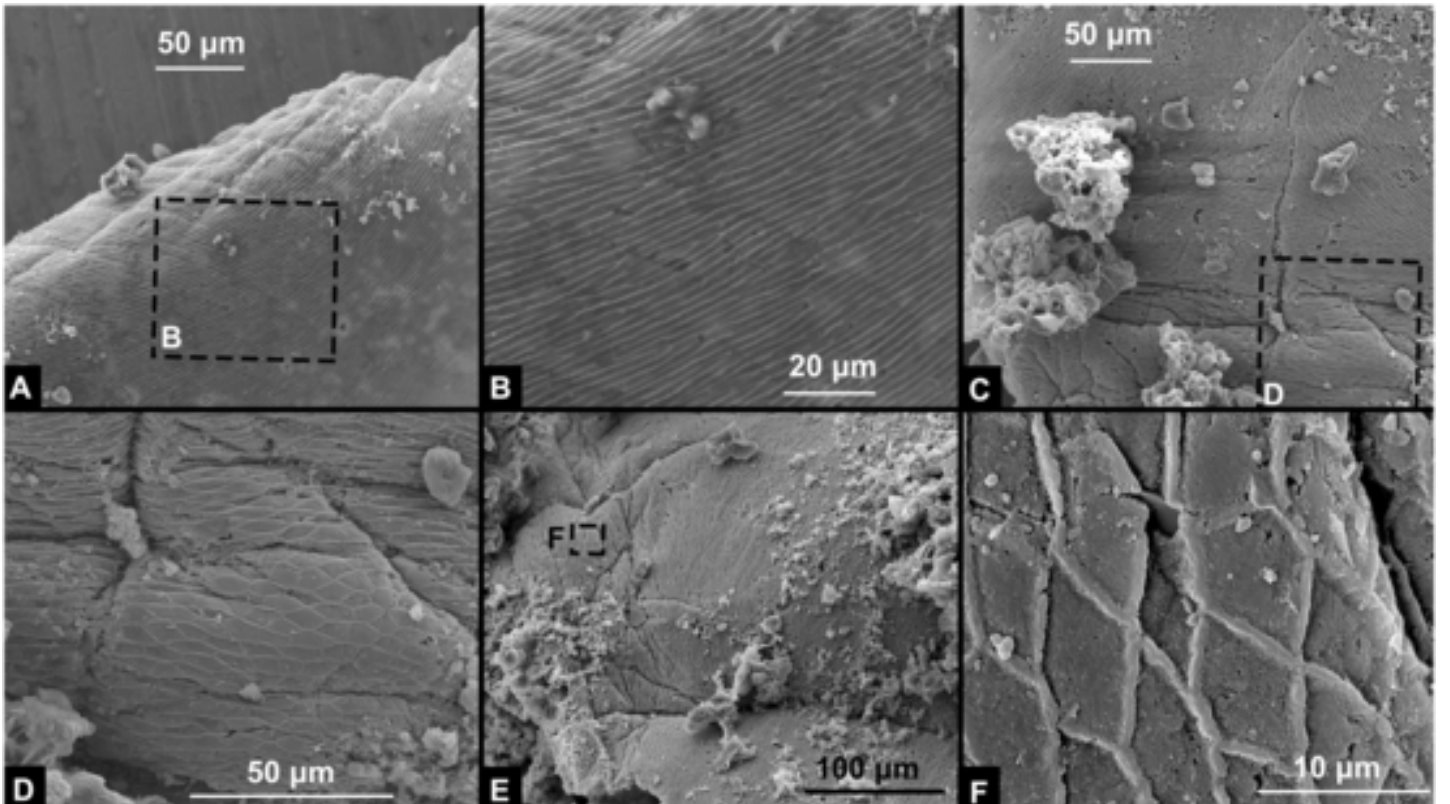

B

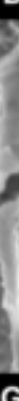

G
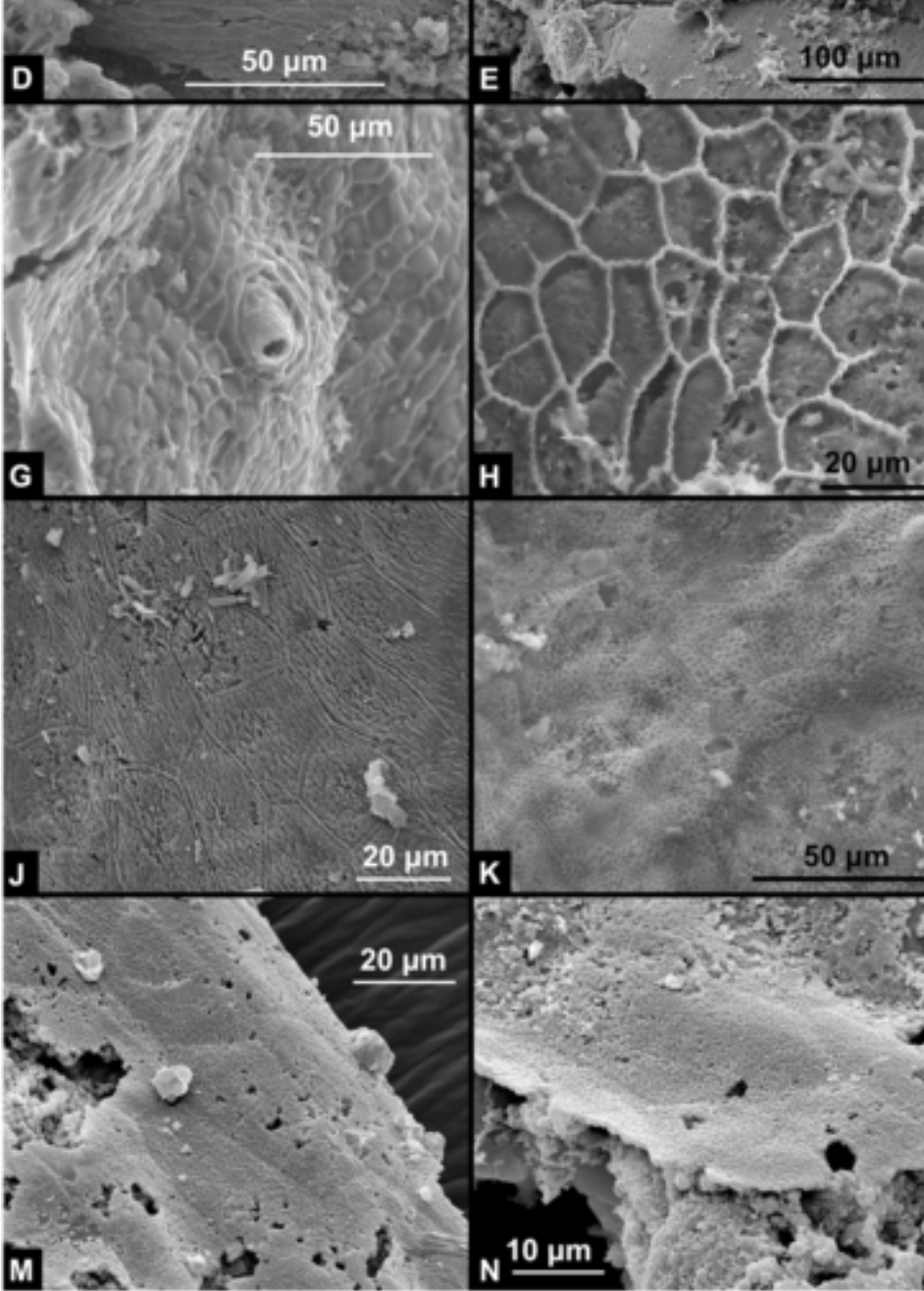

H
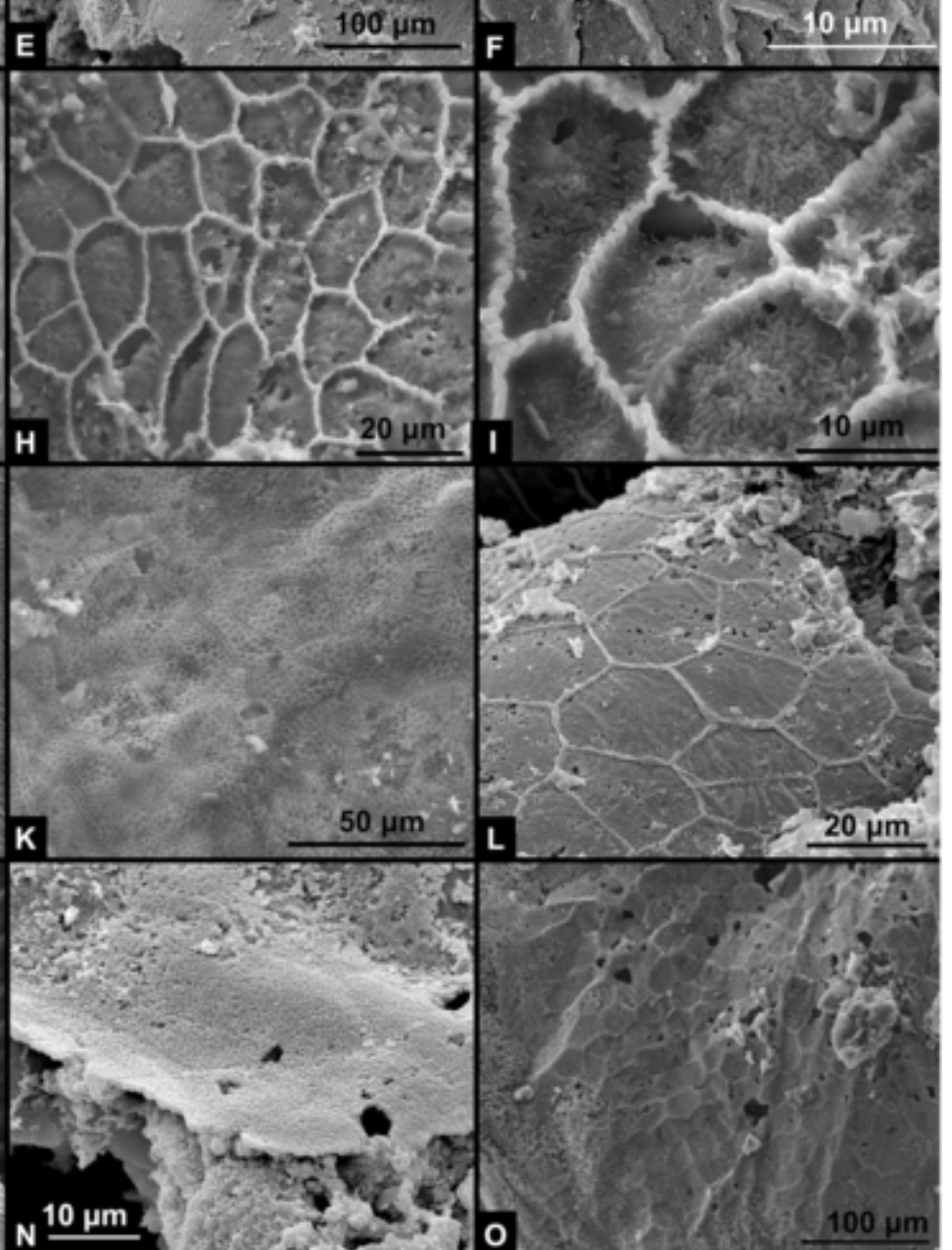

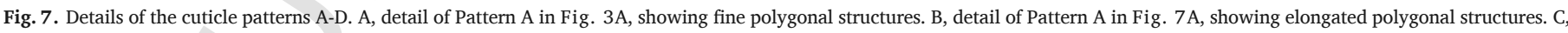

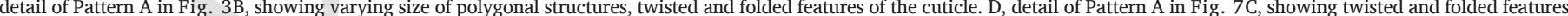

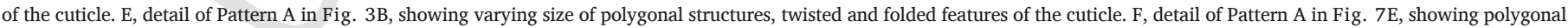

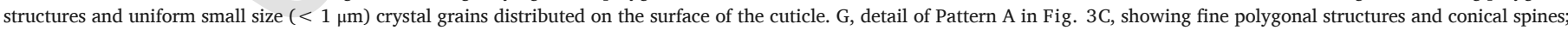

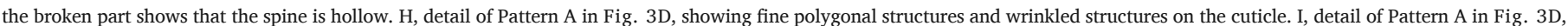
showing fine polygonal structures and wrinkled structures on the cuticle. J, detail of Pattern B in 


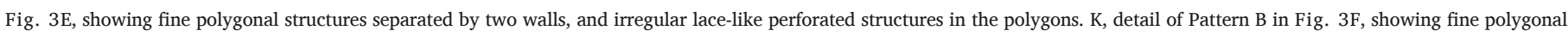

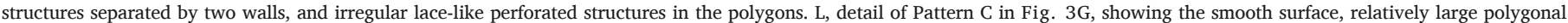

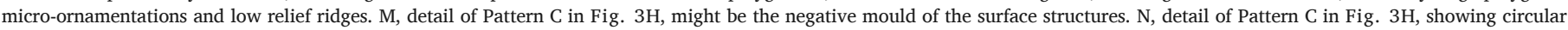
pits with a diameter of about 1.5 microns which might be cell moulds. O, detail of Pattern D in Fig. 3I, showing indistinct boundaries between the polygons.

to more complete specimens found either in the same formation or elsewhere.

\subsection{Modes of fossil preservation and Cambrian bioradiation}

The emergence of metazoans is one of the major events in the history of life that took place during the Ediacaran-Cambrian transition. It revolutionized the global ecosystems, and eventually gave rise to the present-day biological and ecological diversity (e.g. Bengtson, 2002; Conway-Morris, 2006; Chen, 2009). Major anatomical, functional and behavioral innovations occurred during this time interval, which led to an increased complexity of ecological interactions (e.g. food webs), as well as the expansion of ecological space (Maloof et al., 2010; Benton et al., 2015; Wood et al., 2017). These major events are mainly based on various fossil evidence from Ediacaran to Ordovician Lagerstätten (e.g. Jago and Cooper, 2011; Caron et al., 2014; Paterson et al., 2016; Hou et al., 2017; Fu et al., 2019; Harper et al., 2019). SSFs also provide a wealth of information about the early evolution of metazoans. Yet, due to taphonomic bias and the patchiness of fossil record, the basal animal tree is still far from being understood (e.g. Harvey and Butterfield, 2017). Molecular clocks and biomarkers provide independent estimates for the timing of animal origin and early diversification, and suggest that the divergence of major phyla occurred much earlier than the Ediacaran (Erwin et al., 2011; Rota-Stabelli et al., 2013; dos Reis et al., 2015; Parry et al., 2017). It has been suggested that most progenitors of Cambrian animals were probably meiofaunal (Brown et al., 2008; Laumer et al., 2005; Wray, 2015; Han et al., 2017; Harvey and Butterfield, 2017). If so, their tiny size and lack of hard skeletal parts may have dramatically reduced their chance of being fossilized, resulting in virtually no fossil record and therefore in a considerable gap between molecular clock estimates and the fossil records for the deep-time splits in the animal tree (Donoghue et al., 2003; Cunningham et al., 2017; Parry et al., 2017).

Phosphatized soft tissue preservation, occurring from the Ediacaran to the earliest Ordovician, has provided another remarkable window into the early evolution of metazoans (Maas et al., 2006; Bottjer et al., 2019). The oldest secondarily phosphatized metazoans, including embryo-like fossils with a variety of cleavage patterns (Yin et al., 2016), possible post-embryonic stage of gemmules and adult animals, occur in the ca. 610 million-year-old, Weng'an Biota from China ('Orsten'-type preservation sensu lato, Maas et al., 2006; but also see Bottjer et al., 2019, Du et al., 2015; Yin et al., 2015). Compared to the Burgess-type faunas and SSF assemblages, 'Orsten'-type Lagerstätten have the particular advantages to favor the preservation of tiny animals such as the meiofauna. However, ecdysozoans and cuticular remains of possible ecdysozoans origin are virtually absent from the Ediacaran 'Orsten'-type Lagerstätten (Schiffbauer et al., 2014). The 'Orsten'-type fossil record of ecdysozoans becomes frequent at the base of the Cambrian, as illustrated by the ca. 535 Ma old Kuanchuanpu Formation in southern Shaanxi Province (Maas et al., 2006; Zhang et al., 2007; Liu et al., 2014b, 2017; Schiffbauer et al., 2014; Zhang et al., 2015; Zhang et al., 2016a; Han et al., 2017). Cuticular remains attributed to ecdysozoans become abundant and diverse in Cambrian Series
2 (e.g. Zhang et al., 2007, Zhang and Pratt, 2012; this study), which corresponds to the first peak of the ecdysozoan bioradiation recorded by other types of fossils (Li et al., 2007). 'Orsten'-type fossils and other sources of valuable information obtained from SSFs, SCFs and BST-type Lagerstätten, when put together, shed light on the early evolutionary steps of early animal life (e.g. Harvey and Butterfield, 2017; Daley et al., 2018; Bottjer et al., 2019).

\subsection{Metazoan offshore invasion}

According to multiple paleo-redox reconstructions of marine settings based on elemental and isotopic proxies, the early Cambrian Epoch 2, Age 3 ocean was stratified, with heterogeneous oxygenation (Cheng et al., 2017; Li et al., 2017; Li et al., 2008; Zhang et al., 2017; Zhang et al., 2018a; Zhang et al., 2020). A decrease in faunal diversity from shallow to deep environments is in line with the oxygenation gradient in South China (Li et al., 2007). Therefore, the offshore invasion of metazoans during this interval is likely to have been controlled by the oxygenation conditions in the water column (Canfield et al., 2007; Lyons et al., 2014; Zhang et al., 2014; Chen et al., 2015; Li et al., 2017; Liu et al., 2018; Zhang et al., 2018a, 2020). However, exceptions may occur as exemplified by bed 3 of the Qiaojiaping section from which diverse fossil cuticles are reported from limestone nodules (present study, Fig. 14). The studied interval of the Qiaojiaping section was deposited in an offshore environment of the Yangtze Platform (Zhang et al., 2020, Fig. 14). The paleo-redox proxies obtained from bed 3 in the closely located Luojiacun section, indicate that the bottom water was strongly depleted in oxygen (anoxic-suboxic to euxinic; Zhang et al., 2018b) during Cambrian Series 2, Stage 3 (Fig. 14). This is consistent with sedimentological observations, such as the high carbonaceous content, dominance of horizontal lamination or parallel bedding, and absence of bioturbation. In modern oceans, assemblages from poorly oxygenated areas are generally low in diversity, and dominated by small, unmineralized organisms (Bowyer et al., 2017). Very few organisms are able to live in or close to the sediment-water interface in the absence of dissolved oxygen (Danovaro et al., 2010). The diverse assemblages described here are found in assumed anoxic-suboxic to euxinic depositional environments (Zhang et al., 2018c). Meiofauna, which live in interstitial microenvironments between sand grains where water circulates, can survive in oxygen-depleted or anoxic conditions (e.g. Danovaro et al., 2010). The 'Orsten'-type assemblages from the Alum Shale Formation in Southern Sweden mainly consist of autochthonous (and paraautochtonous) tiny arthropods and allies interpreted as epibenthic organisms which inhabited diverse niches within the unconsolidated, flocculent detrital zone above the poorly oxygenated (dysoxic to anoxic) seafloor (Müller and Walossek, 1985; Tang, 2002; Maas et al., 2006; Maeda et al., 2011). The average size of the specimens investigated here (e.g. Fig. 2J), if complete, would fall outside the range of the meiofauna (from $32 \mu \mathrm{m}$ to $1,000 \mu \mathrm{m}$ in size according to Giere, 2008 and Parry et al., 2017). In addition, phosphatized carapaces of Isoxys (Fig. 2I) interpreted as pelagic animals are found associated with cuticular remains. An alternative option is that some of the cuticle-bearing organisms inhab- 


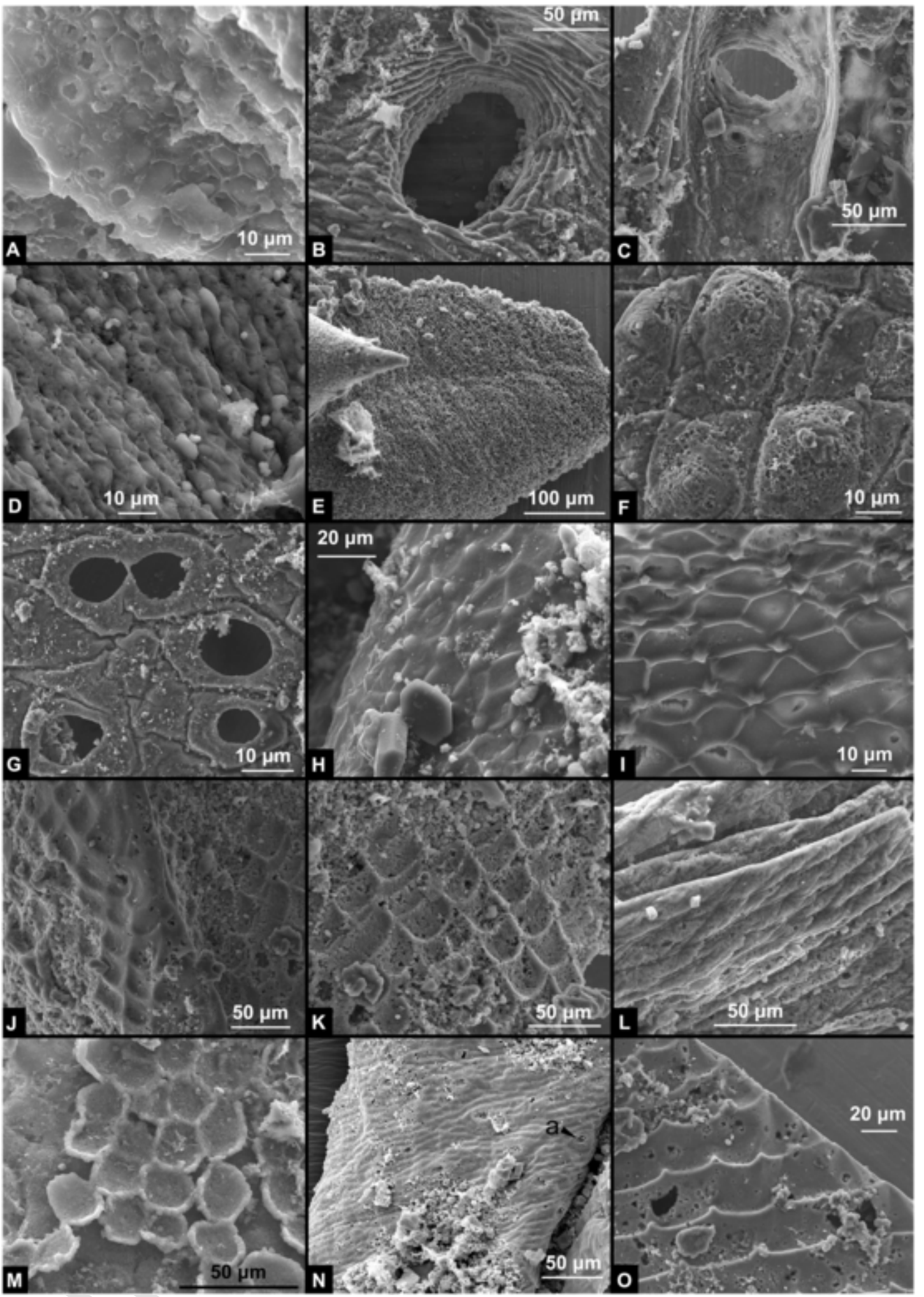

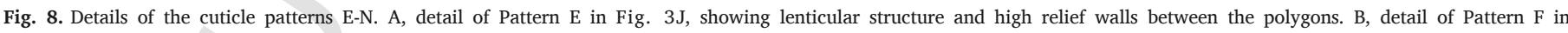

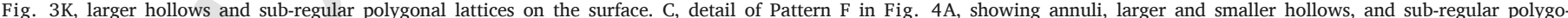

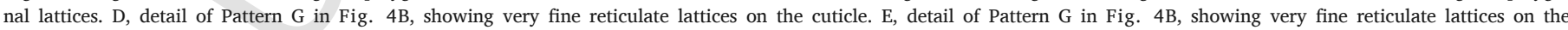

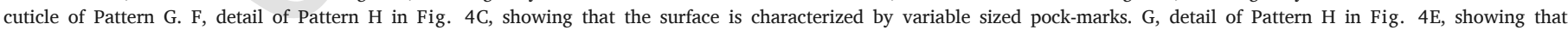

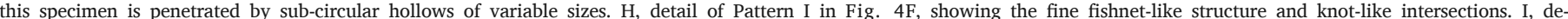

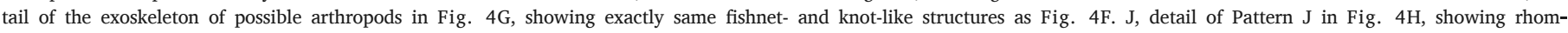




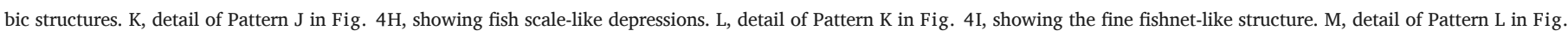

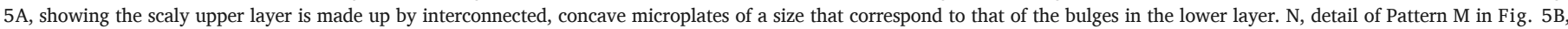

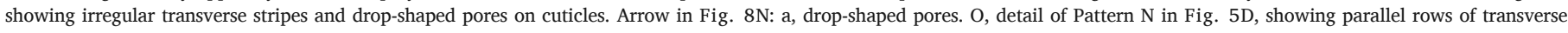
serrate terraces and small tips occur on the terraces.

ited more oxygenated waters in adjacent areas, either in the middle-upper part of the water column and/or at the water sediment interface (Jin et al., 2014; Zhang et al., 2018b). After death, the pelagic organisms would have settled on the sea floor, whereas epibenthic elements would have been transported from their original habitat by storm events or turbidity currents (Maeda et al., 2011; Fu et al., 2019, Fig. 14). Generally, soft carcasses decompose extremely fast after death under oxygenated conditions (Eriksson et al., 2012, 2016; Murdock et al., 2014; Zhang et al., 2016b; Harper et al., 2019). Incomplete phosphatization of carcasses may have led to fragmentation without current intervention (Maas et al., 2006). The lack of evidence for obrution and major periodic sediment inputs such as tempestites in bed 3 of the Shuijingtuo Formation suggests that transportation should have been very limited. It should be noted that these two possibilities (meiofauna v.s. transportation) are not mutually exclusive. The fossil assemblages may come from different sources (Fig. 14). Whatever their origin (meiofaunal and/or pelagic animals), we suggest that the cuticular fossil elements from Shuijingtuo Formation are mostly autochthonous or parautochthonous (Fig. 14).

Current views hold that the peak of metazoan diversification was slightly delayed in offshore settings compared to nearshore areas ( $\mathrm{Li}$ et al., 2017; Zhang et al., 2020). However, our results are consistent with recent studies that described highly diversified marine faunas in relatively deeper-water depositional areas, typically the Qingjiang Lagerstätte that is supposed to be even more diverse than the Chengjiang Lagerstätte (Fu et al., 2019; Zhang et al., 2020). The abundant and diverse cuticles reported herein could suggest that the invasion of metazoans into offshore environments closely followed, or was even simultaneous to, their radiation in shallower water equivalents.

\section{Conclusions}

A variety of 'Orsten'-type fossils are described here from the upper Shuijingtuo Formation (eastern Three Gorges area, China; Cambrian Series 2 , Stage 3 ). They are mainly represented by fragments deposited in a relatively deep shelf setting. At least seventeen ornamentation patterns are recognized on these fragments. Most of them are cuticular remains of ecdysozoans animals such as arthropods and palaeoscolecid worms; others may belong to brachiopods and/or mollusks. The original habitat of these organisms remains uncertain. Some of them may have lived within the water column and sank down to the bottom after death, while others (e.g. epibenthic species) may have been transported and fragmented by currents to be eventually accumulated in the depositional area. Some may also be partly preserved cuticles, i.e. resulting from an incomplete phosphatization of more complete carcasses. The diverse cuticles provide a coherent picture of the Cambrian bioradiation recorded by the 'Orsten'-type and other preservations. The new fossil material would indicate animals colonized off-shore environments very shortly after and even during the animal biodiversification.

\section{Uncited references}

Grazhdankin et al., 2020

Jin et al., 2016

Maas et al., 2007

Paterson et al., 2011

Sahoo et al., 2016

Yin et al., 2019

\section{Declaration of Competing Interest}

The authors declared that they have no conflicts of interest to this work.

\section{Acknowledgments}

This work was supported by National Natural Science Foundation of China (grants 41972024, 41430101, 41502014, 41890843). We thank Wei Guo and Yuhao Yi for their help with SEM work. Prof. Yunhuan Liu and Dr. Ben Yang are acknowledged for their detailed guidance during the chemical processes. Dr. Min Shi, Tao Dai, Deng Wang and Zhiliang Zhang are acknowledged for constructive discussions during the preparation of the manuscript. Special thanks are due to two anonymous reviewers for their constructive remarks on the manuscript. We thank the editor Prof. Thomas Algeo for editorial input. 


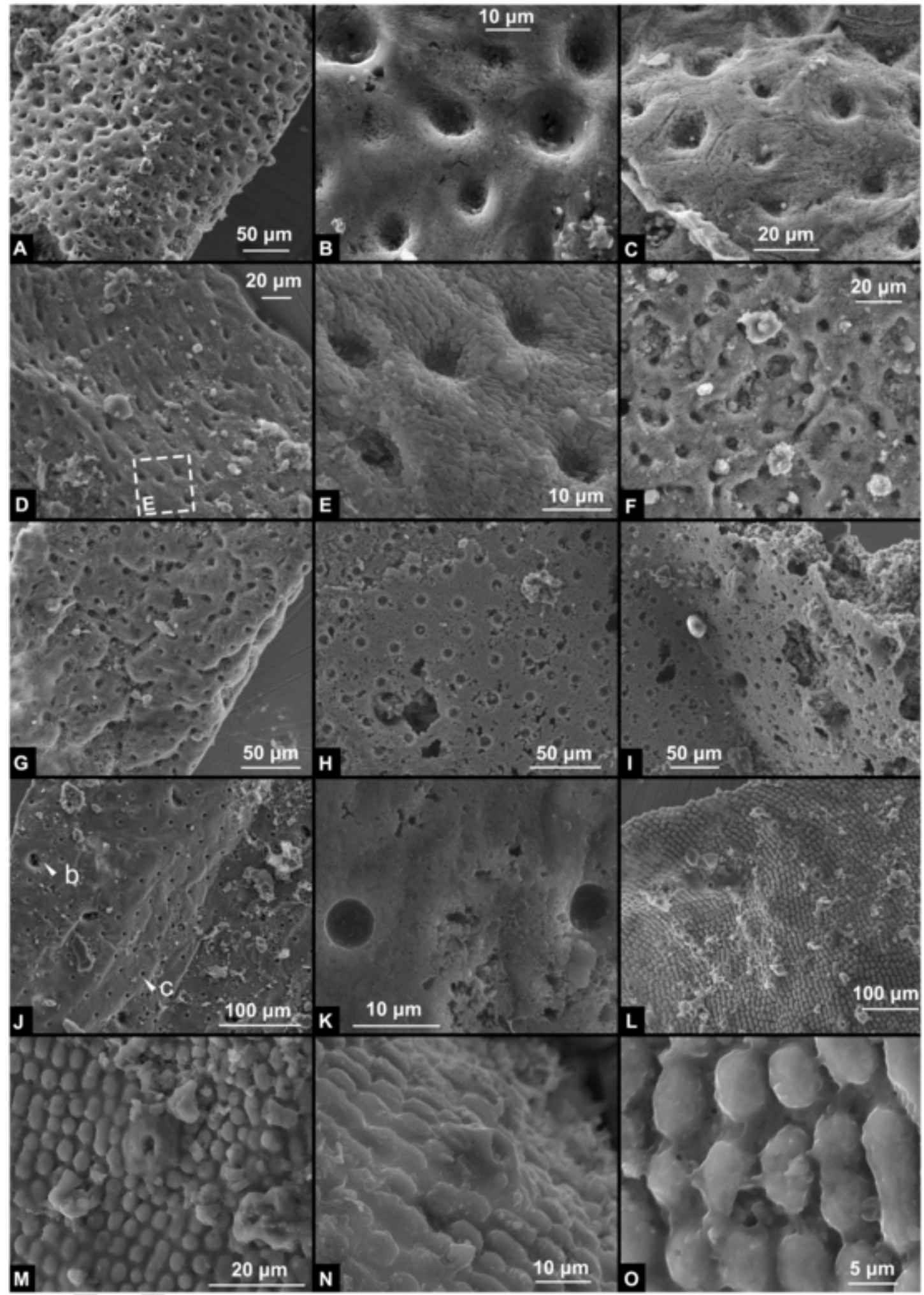

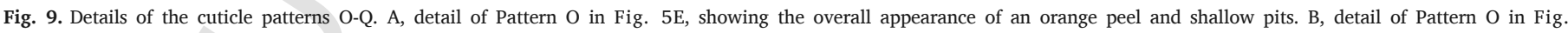

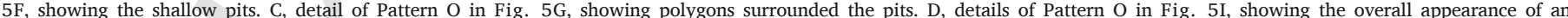

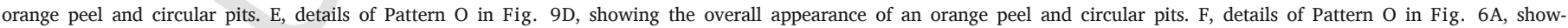

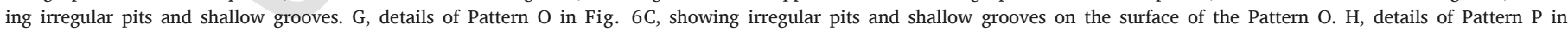

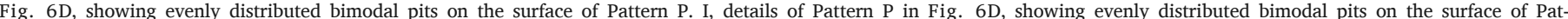

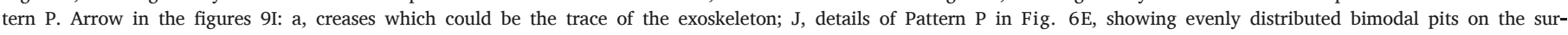




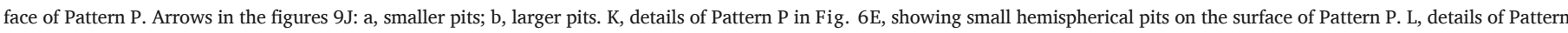

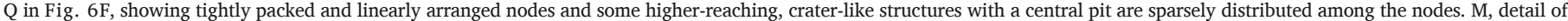

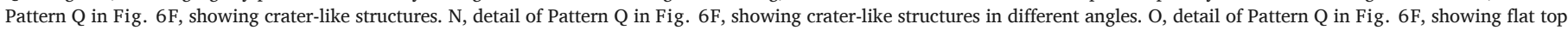
surface, relatively uniform of the height and the irregular maximal length of the nodes.

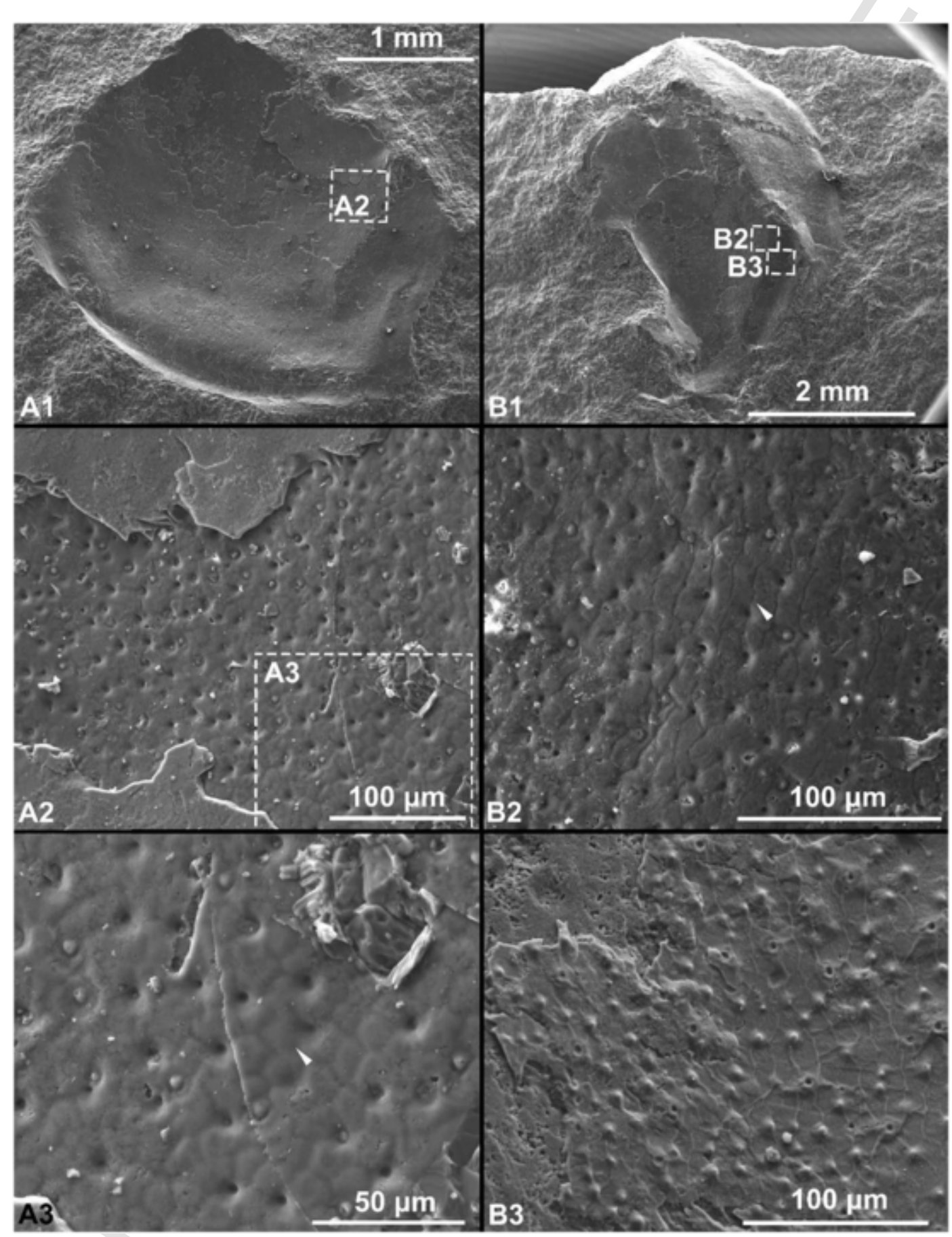

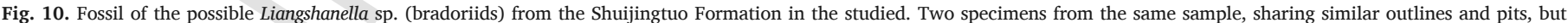
with slightly different polygonal patterns (see arrows in B1 and A2) on the surface of the shales. A, No. 17SPC-25-2/001, B, No. 17SPC-25-2/001. 


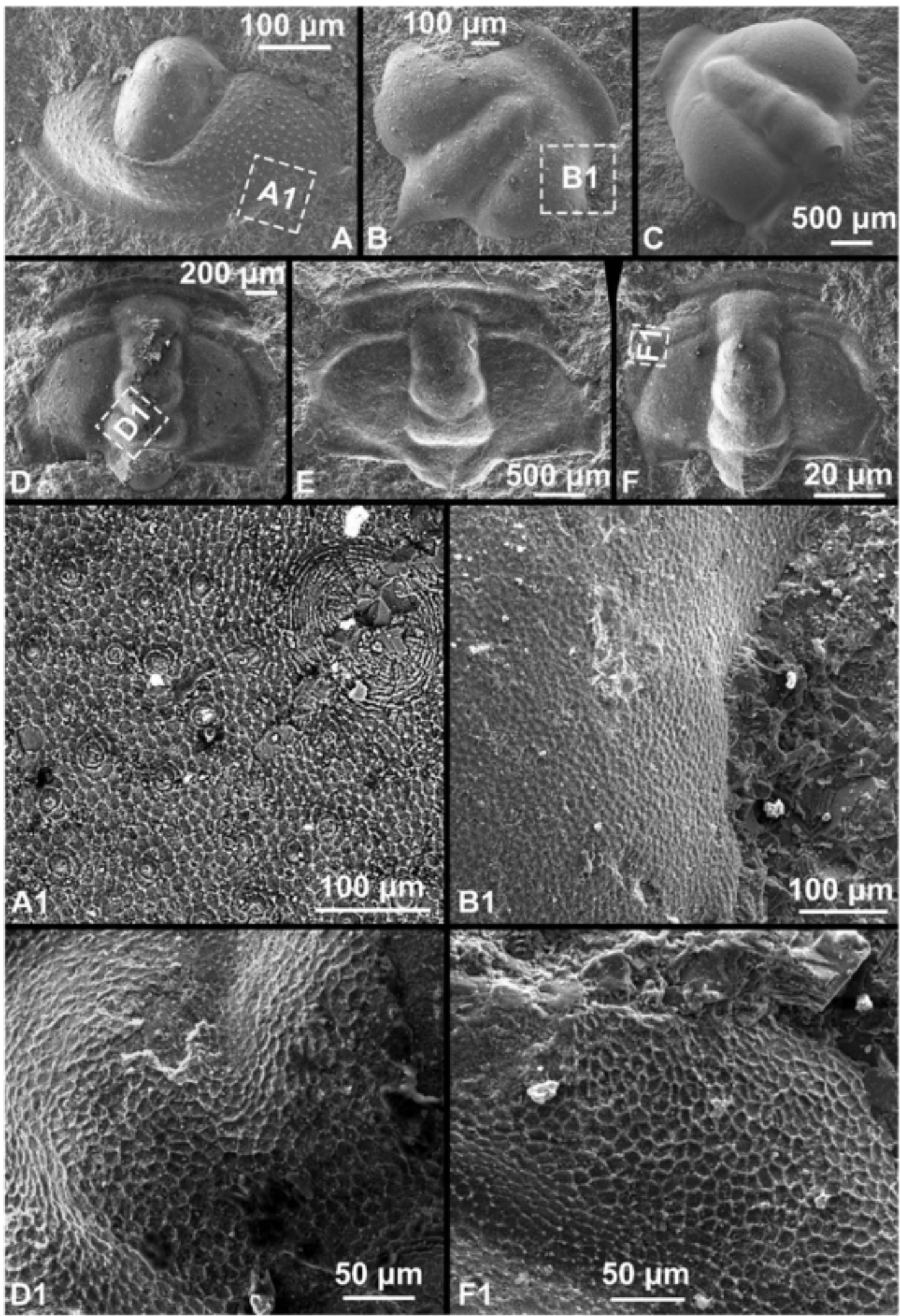

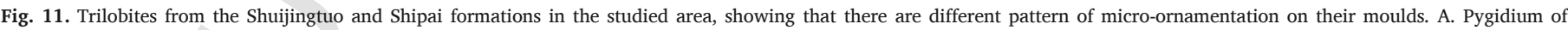

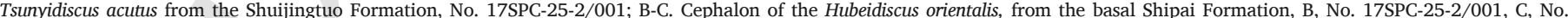
17SPC-25-2/001; D-F, Cephalon of an undetermined trilobite, from the Shuijingtuo Formation, D, No. 17SPC-25-2/001, E, No. 17SPC-25-2/001, F, No. 17SPC-25-2/001. 


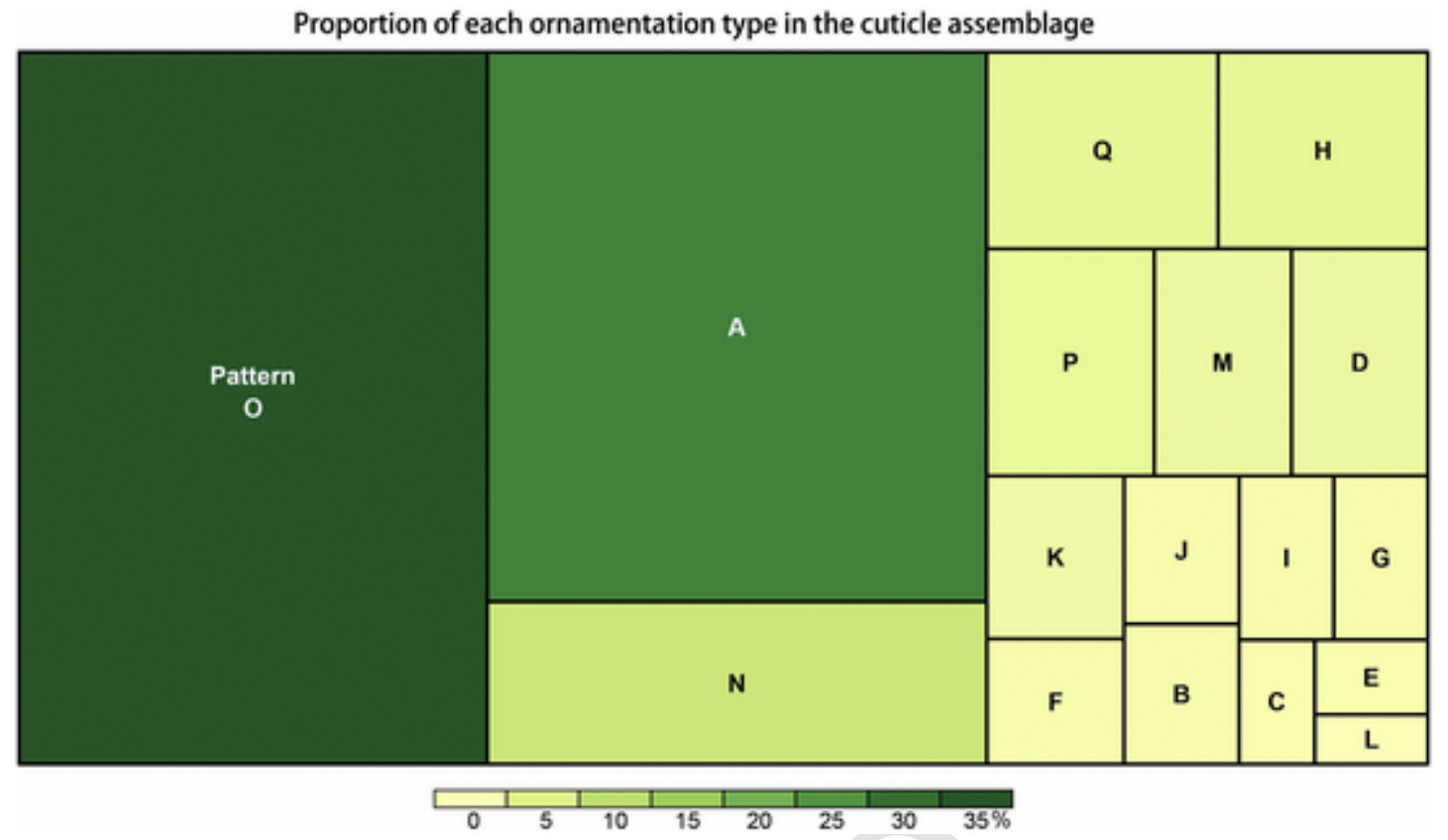

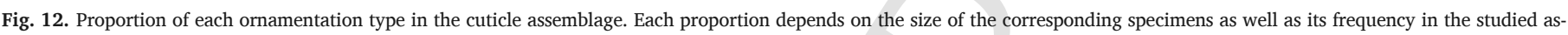

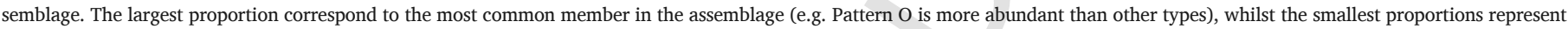

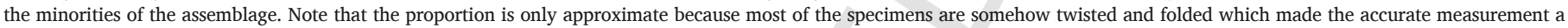
very hard task. See original quantitative data in Table 1. 
L. Chang et al.

Palaeogeography, Palaeoclimatology, Palaeoecology $x x x$ ( $x x x x) x x x x-x x x$

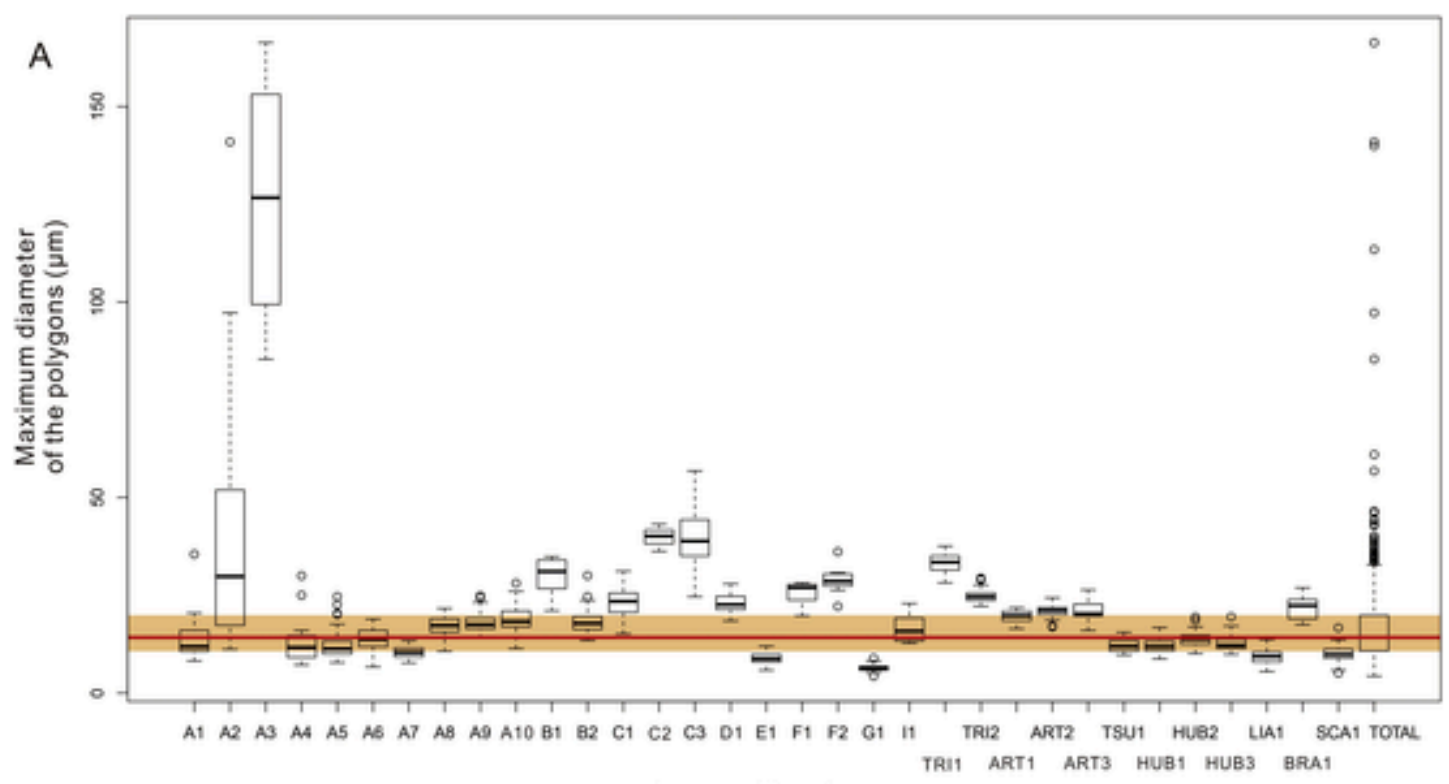

specimens with polygons

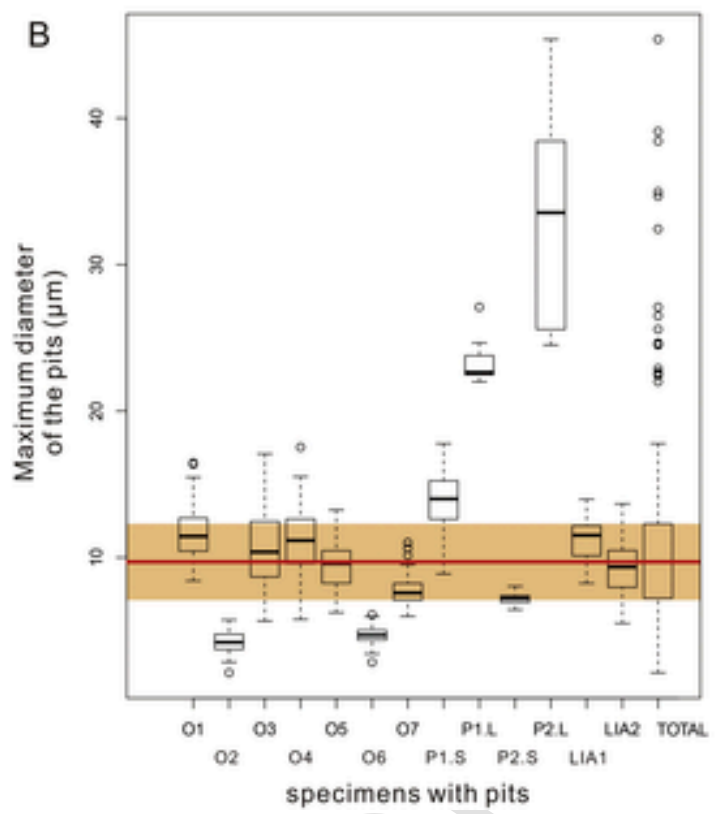

Fig. 13. Boxplots showing measurements of maximal size of polygons (A) and pits (B) on cuticles from the Cambrian (Series 2) Shuijingtuo Formation and comparison with similar patterns on shells, compound eyes, epithelial cell moulds found from the Shuijingtuo and Kuanchuanpu formations, showing that there is no clear boundary between the length, width and their ratio for most patterns except for the polygons which are particularly large or small. Cuticle fossils of scalidophoran worms from Wang et al. (2019). Original data of this figure can be found in Table 1.

27 


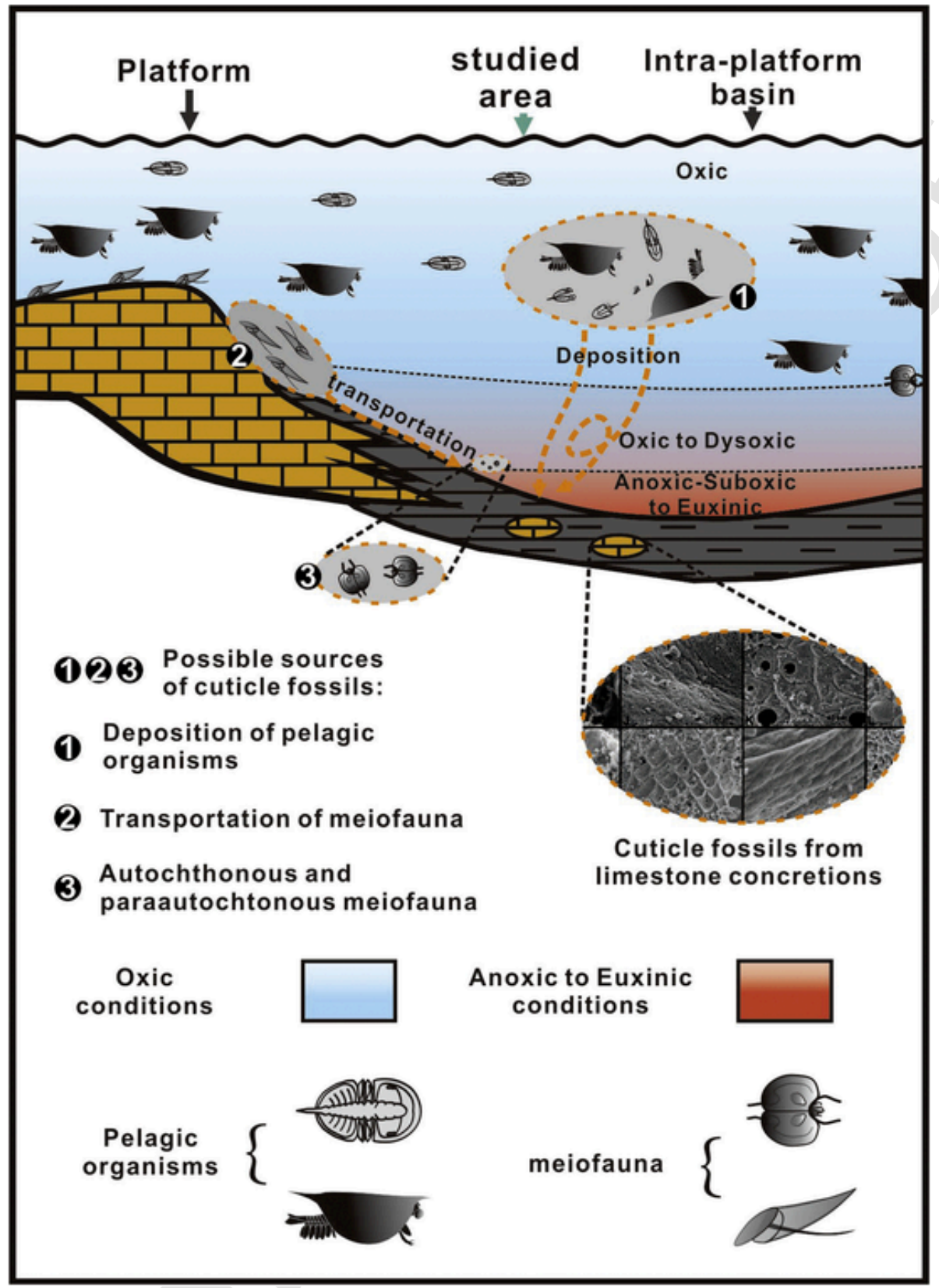

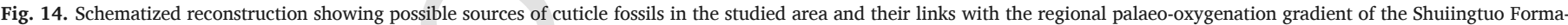
tion. Palaeoceanographic reconstruction modified from Chen et al. (2018).

\section{References}

Agić, H., Moczydłowska, M., Yin, L., 2017. Diversity of organic-walled microfossils from the early Mesoproterozoic Ruyang Group, North China Craton - A window into the early eukaryote evolution. Precambr. Res. 297, 101-130.

Ahn, S., Zhu, M., 2017. Lowermost Cambrian acritarchs from the Yanjiahe Formation, South China: implication for defining the base of the Cambrian in the Yangtze Platform. Geol. Mag. 154, 1217-1231.

Bailey, J.V., Joye, S.B., Kalanetra, K.M., Flood, B.E., Corsetti, F.A., 2007. Evidence of giant sulphur bacteria in Neoproterozoic phosphorites. Nature 445, 198-201.

Bengtson, S., 2002. Origins and early evolution of predation. Paleontol. Soc. Papers 8 , 289-318.

Bengtson, S., Yu, Z., 1997. Fossilized metazoan embryos from the earliest Cambrian. Science 277, 1645-1648.
Benton, M.J., Donoghue, P.C., Asher, R.J., Friedman, M., Near, T.J., Vinther, J., 2015 Constraints on the timescale of animal evolutionary history. Palaeontol. Electron. 18, $1-06$.

Bottjer, D.J., Yin, Z., Zhao, F., Zhu, M., 2019. Comparative taphonomy and phylogenetic signal of phosphatized Weng'an and Kuanchuanpu Biotas. Precambr. Res. 105408.

Bowyer, F., Wood, R.A., Poulton, S.W., 2017. Controls on the evolution of Ediacaran metazoan ecosystems: a redox perspective. Geobiology 15, 516-551.

Bradbury, J.W., Vehrencamp, S.L., 1998. Principles of animal communication. 2nd ed. Sinauer Associates.

Briggs, D.E., 2003. The role of decay and mineralization in the preservation of soft-bodied fossils. Annu. Rev. Earth Planet. Sci. 31, 275-301.

Broce, J., Schiffbauer, J.D., Sen Sharma, K., Wang, G., Xiao, S., 2014. Possible animal embryos from the lower Cambrian (Stage 3) Shuijingtuo Formation, Hubei Province, South China. J. Paleontol. 88, 385-394.

Broda, K., Zatoń, M., 2017. A set of possible sensory system preserved in cuticle of Late Devonian thylacocephalan arthropods from Poland. Hist. Biol. 29, 1045-1055. 
Brown, F.D., Prendergast, A., Swalla, B.J., 2008. Man is but a worm: chordate origins. genesis 46, 605-613.

Butler, A.D., Cunningham, J.A., Budd, G.E., Donoghue, P.C., 2015. Experimental taphonomy of Artemia reveals the role of endogenous microbes in mediating decay and fossilization. P. Roy. Soc. B-Biological Sciences 282, 20150476.

Butterfield, N.J., 1990. Organic preservation of non-mineralizing organisms and the taphonomy of the Burgess Shale. Paleobiol. 272-286.

Butterfield, N.J., 2003. Exceptional fossil preservation and the Cambrian explosion. Integr. Comp. Biol. 43, 166-177.

Butterfield, N.J., 2008. An early Cambrian radula. J. Paleontol. 82, 543-554.

Butterfield, N.J., Harvey, T.H.P., 2012. Small carbonaceous fossils (SCFs): a new measure of early Paleozoic Paleobiology. Geology 40, 71-74.

Canfield, D.E., Poulton, S.W., Narbonne, G.M., 2007. Late-Neoproterozoic deep-ocean oxygenation and the rise of animal life. Science 315, 92-95.

Caron, J.B., Smith, M.R., Harvey, T.H., 2013. Beyond the Burgess Shale: Cambrian microfossils track the rise and fall of hallucigeniid lobopodians. P. Roy. Soc. B-Biological Sciences 280, 20131613.

Caron, J.B., Gaines, R.R., Aria, C., Mángano, M.G., Streng, M., 2014. A new phyllopod bed-like assemblage from the Burgess Shale of the Canadian Rockies. Nat. Commun. 5,3210 .

Castellani, C., Haug, J.T., Haug, C., Maas, A., Schoenemann, B., Waloszek, D., 2012. Exceptionally well-preserved isolated eyes from Cambrian 'Orsten' fossil assemblages of Sweden. Palaeontology 55, 553-566.

Chang, S., Clausen, S., Zhang, L., Feng, Q., Steiner, M., Bottjer, D.J., Zhang, Y., Shi, M., 2018. New probable cnidarian fossils from the lower Cambrian of the Three Gorges area, South China, and their ecological implications. Palaeogeogr., Palaeoclimat., Palaeoecol. 505, 150-166.

Chang, S., Zhang, L., Clausen, S., Bottjer, D.J., Feng, Q., 2019. The Ediacaran-Cambrian rise of siliceous sponges and development of modern oceanic ecosystems. Precambr. Res. 333, 105438. https://doi.org/10.1016/j.precamres.2019.105438.

Chen, J., 2009. The sudden appearance of diverse animal body plans during the Cambrian explosion. Int. J. Dev. Biol. 53, 733-751.

Chen, X., Ling, H., Vance, D., Shields-Zhou, G.A., Zhu, M., Poulton, S.W., Och, L.M., Jiang, S., Li, D., Cremonese, L., Archer, C., 2015. Rise to modern levels of ocean oxygenation coincided with the Cambrian radiation of animals. Nat. Commun. 6, 7142.

Chen, X., Wei, K., Zhang, B., Li, P., Li, H., Liu, A., Luo, S., 2018. Main geological factors controlling shale gas reservoir in the Cambrian Shuijingtuo Formation in Yichang of Hubei Province as well as its and enrichment patterns. Geol. China 45, 207-226 (in Chinese with English abstract).

Cheng, M., Li, C., Zhou, L., Feng, L., Algeo, T.J., Zhang, F., Romaniello, S., Jin, C., Ling, H., Jiang, S., 2017. Transient deep-water oxygenation in the early Cambrian Nanhua Basin, South China. Geochim. Cosmochim. Acta 210, 42-58.

Cohen, P.A., Knoll, A.H., Kodner, R.B., 2009. Large spinose microfossils in Ediacaran rocks as resting stages of early animals. PNAS 106, 6519-6524.

Conway-Morris, S., 2006. Darwin's dilemma: the realities of the Cambrian 'explosion'. Philos T Roy Soc B-Biological Sciences 361, 1069-1083.

Crowe, J.H., Newell, I.M., Thomson, W.W., 1970. Echiniscus viridis (Tardigrada): Fine structure of the cuticle. T. American Micro. Soc. 316-325.

Cunningham, J.A., Thomas, C.W., Bengtson, S., Kearns, S.L., Xiao, S., Marone, F., Stampanoni, M., Donoghue, P.C., 2012. Distinguishing geology from biology in the Ediacaran Doushantuo biota relaxes constraints on the timing of the origin of bilaterians. P. Roy. Soc. B-Biological Sciences 279, 2369-2376.

Cunningham, J.A., Liu, A.G., Bengtson, S., Donoghue, P.C., 2017. The origin of animals: can molecular clocks and the fossil record be reconciled? BioEssays 39, 1-12.

Dai, T., Zhang, X., 2011. Ontogeny of the Eodiscoid Trilobite Tsunyidiscus acutus from the lower Cambrian of South China. Palaeontology 54, 1279-1288.

Daley, A.C., Antcliffe, J.B., Drage, H.B., Pates, S., 2018. Early fossil record of Euarthropoda and the Cambrian Explosion. PNAS 115, 5323-5331.

Danovaro, R., Dell'Anno, A., Pusceddu, A., Gambi, C., Heiner, I., Kristensen, R.M., 2010. The first metazoa living in permanently anoxic conditions. BMC Biol. 8, 1-10.
Dong, X., Donoghue, P.C., Cunningham, J.A., Liu, J., Cheng, H., 2005a. The anatomy, affinity, and phylogenetic significance of Markuelia. Evol. Dev. 7, 468-482.

Dong, X., Donoghue, P.C., Liu, Z., Liu, J., Peng, F., 2005b. The fossils of 'Orsten'-type preservation from Middle and Upper Cambrian in Hunan. China. Chinese Sci. Bul. 50, 1352-1357.

Donoghue, P.C., Smith, M.P., Sansom, I.J., 2003. The origin and early evolution of chordates: molecular clocks and the fossil record. Telling the evolutionary time: molecular clocks and the fossil record. pp. 190-223.

Dornbos, S.Q., 2011. Phosphatization through the Phanerozoic. In: Allison, P.A., Bottjer, D.J. (Eds.), Taphonomy. Springer, Dordrecht, pp. 435-456.

Dos Reis, M., Thawornwattana, Y., Angelis, K., Telford, M.J., Donoghue, P.C., Yang, Z., 2015. Uncertainty in the timing of origin of animals and the limits of precision in molecular timescales. Curr. Biol. 25, 2939-2950.

Du, W., Wang, X., Komiya, T., 2015. Potential Ediacaran sponge gemmules from the Yangtze Gorges area in South China. Gondwana Res. 28, 1246-1254.

Eriksson, M.E., Terfelt, F., Elofsson, R., Marone, F., 2012. Internal soft-tissue anatomy of Cambrian 'Orsten' arthropods as revealed by synchrotron X-ray tomographic microscopy. PLoS ONE 7, e42582. doi:10.1371/journal.pone.0042582.

Eriksson, M.E., Terfelt, F., Elofsson, R., Maas, A., Marone, F., Lindskog, A., Waloszek, D., Schmitz, B., Stampanoni, M., 2016. Baring it all: undressing Cambrian 'Orsten' phosphatocopine crustaceans using synchrotron radiation X-ray tomographic microscopy. Lethaia 49, 312-326.

Erwin, D.H., Laflamme, M., Tweedt, S.M., Sperling, E.A., Pisani, D., Peterson, K.J., 2011. The Cambrian conundrum: early divergence and later ecological success in the early history of animals. Science 334, 1091-1097.

Fu, D., Zhang, X., Budd, G.E., Liu, W., Pan, X., 2014. Ontogeny and dimorphism of Isoxys auritus (Arthropoda) from the Early Cambrian Chengjiang biota, South China. Gondwana Res. 25, 975-982.

Fu, D., Tong, G., Dai, T., Liu, W., Yang, Y., Zhang, Y., Cui, L., Li, L., Yun, H., Wu, Y., Sun, A., Liu, C., Pei, W., Gaines, R., Zhang, X., 2019. The Qingjiang biota-A Burgess Shale-type fossil Lagerstätte from the early Cambrian of South China. Science 363, 1338-1342.

Gaines, R.R., Hammarlund, E.U., Hou, X.G., Qi, C.S., Gabbott, S.E., Zhao, Y.L., Peng, J., Canfield, D.E., 2012. Mechanism for Burgess Shale-type preservation. locks. P. Natl. Acad. Sci. U.S.A. $109,5180-5184$.

Giere, O., 2008. Meiobenthology: the microscopic motile fauna of aquatic sediments. Springer Science \& Business Media.

Glaessner, M.F., 1979. Lower Cambrian Crustacea and annelid worms from Kangaroo Island, South Australia. Alcheringa 3, 21-31.

Grazhdankin, D., Nagovitsin, K., Golubkova, E., Karlova, G., Kochnev, B., Rogov, V., Marusin, V., 2020. Doushantuo-Pertatataka-type acanthomorphs and Ediacaran ecosystem stability. Geology. https://doi.org/10.1130/G47467.1.

Guo, J., Li, Y., Han, J., Zhang, X., Zhang, Z., Ou, Q., Shu, D., 2009. Discovery of protoconites genus from Yanjiahe Formation Terreneuvian of the Three Gorge area, South China. Prog. Nat. Sci. 19, 180-184 (in Chinese with English abstract).

Guo, J., Li, Y., Li, G., 2014. Small shelly fossils from the early Cambrian Yanjiahe Formation, Yichang, Hubei, China. Gondwana Res. 25, 999-1007.

Han, J., Conway Morris, S., Ou, Q., Shu, D., Huang, H., 2017. Meiofaunal deuterostomes from the basal Cambrian of Shaanxi (China). Nature 542, 228-232.

Harper, D.A., Hammarlund, E.U., Topper, T.P., Nielsen, A.T., Rasmussen, J.A., Park, T.Y.S., Smith, M.P., 2019. The Sirius Passet Lagerstätte of North Greenland: a remote window on the Cambrian Explosion. J. Geol. Soc. London 176, 1023-1037.

Harvey, T.H., Butterfield, N.J., 2017. Exceptionally preserved Cambrian loriciferans and the early animal invasion of the meiobenthos. Nat. Ecol. Evol. 1, 1-5.

Harvey, T.H., Ortega-Hernández, J., Lin, J., Zhao, Y., Butterfield, N.J., 2012. Burgess Shale-type microfossils from the middle Cambrian Kaili Formation, Guizhou Province, China. Acta. Palaeontol. Pol. 57, 423-436.

Haug, J.T., Huebers, M., Haug, C., Maas, A., Waloszek, D., Schneider, J.W., Kerp, H.A.N.S., 2014. Arthropod cuticles from the upper Viséan (Mississippian) of eastern Germany. B. Geosci. 89, 541-552.

Hou, X., Bergström, J., 1994. Palaeoscolecid worms may be nematomorphs rather than annelids. Lethaia 27, 11-17. 
Hou, X., H., Siveter, D.J., Siveter, D.J., Aldridge, R.J., Cong, P., Gabbott, S.E., Ma. X., Purnell, M.A., Williams, M., 2017. The Cambrian fossils of Chengjiang, China: the flowering of early animal life. 2nd edn. NY: Wiley-Blackwell.

Hua, H., Chen, Z., Yuan, X.L., Zhang, L., Xiao, S.H., 2005. Skeletogenesis and asexual reproduction in the earliest biomineralizing animal Cloudina. Geology 33 (4), 277-280.

Huldtgren, T., Cunningham, J.A., Yin, C., Stampanoni, M., Marone, F., Donoghue, P.C., Bengtson, S., 2011. Fossilized nuclei and germination structures identify Ediacaran "animal embryos" as encysting protists. Science 334, 1696-1699.

Ishikawa, T., Ueno, Y., Komiya, T., Sawaki, Y., Han, J., Shu, D., Li, Y., Maruyama, S., Yoshida, N., 2008. Carbon isotope chemostratigraphy of a Precambrian/Cambrian boundary section in the Three Gorge area, South China: prominent global-scale isotope excursions just before the Cambrian Explosion. Gondwana Res. 14, 193-208.

Ivantsov, A.Y., Wrona, R., 2004. Articulated palaeoscolecid sclerite arrays from the Lower Cambrian of eastern Siberia. Acta. Palaeontol. Pol. 54, 1-22.

Jago, J.B., Cooper, B.J., 2011. The Emu Bay Shale lagerstätte: a history of investigations. Aust. J. Earth Sci. 58, 235-241.

Jin, C., Li, C., Peng, X., Cui, H., Shi, W., Zhang, Z., Luo, G., Xie, S., 2014. Spatiotemporal variability of ocean chemistry in the early Cambrian, South China. Sci. China Earth Sci. 57, 579-591.

Jin, C., Li, C., Algeo, T.J., Planavsky, N.J., Cui, H., Yang, X., Zhao, Y., Zhang, X., Xie, S., 2016. A highly redox-heterogeneous ocean in South China during the early Cambrian ( $\sim$ 529-514 Ma): Implications for biota-environment co-evolution. Earth Planet. Sci. Let. 441, 38-51.

Kouchinsky, A., Bengtson, S., Clausen, S., Vendrasco, M.J., 2013. An early Cambrian fauna of skeletal fossils from the Emyaksin Formation, northern Siberia. Acta. Palaeontol. Pol. 60, 421-512.

Laumer, C.E., Bekkouche, N., Kerbl, A., Goetz, F., Neves, R.C., Sørensen, M.V., Kristensen, R.M., Hejnol, A., Dunn, C.W., Giribet, G., Worsaae, K., 2005. Spiralian phylogeny informs the evolution of microscopic lineages. Curr. Biol. 25, 2000-2006.

Li, G., Zhu, M., Steiner, M., 2003. Microstructure and functional morphology of the Early Cambrian problematical fossil Rhombocorniculum. Prog. Nat. Sci. 13, 831-835.

Li, G., Steiner, M., Zhu, X., Yang, A., Wang, H., Erdtmann, B.D., 2007. Early Cambrian metazoan fossil record of South China: Generic diversity and radiation patterns. Palaeogeogr., Palaeoclimat., Palaeoecol. 254, 229-249.

Li, Z., Bogdanova, S.V., Collins, A.S., Davidson, A., De Waele, B., Ernst, R.E., Fitzsimons, I.C.W., Fuck, R.A., Gladkochub, D.P., Jacobs, J., Karlstrom, K.E., 2008. Assembly, configuration, and break-up history of Rodinia: a synthesis. Precambr. Res. 160, 179-210.

Li, C., Jin, C., Planavsky, N.J., Algeo, T.J., Cheng, M., Yang, X., Zhao, Y., Xie, S., 2017. Coupled oceanic oxygenation and metazoan diversification during the early-middle Cambrian? Geology 45, 743-746.

Li, L., Zhang, X., Skovsted, C.B., Yun, H., Li, G., Pan, B., 2019. Shell microstructures of the helcionelloid mollusc Anabarella australis from the lower Cambrian (Series 2) Xinji Formation of North China. J. System. Palaeontol. 1-11.

Liu, Z., Zhang, H., 2017. A review on progress on Cambrian Orsten-type fossils in South China. Acta Micropalaeontol. Sin. 34, 1-15 (in Chinese with English abstract).

Liu, P., Xiao, S., Yin, C., Chen, S., Zhou, C., Li, M., 2014a. Ediacaran acanthomorphic acritarchs and other microfossils from chert nodules of the upper Doushantuo Formation in the Yangtze Gorges area, South China. J. Paleontol. 92, 87-98.

Liu, Y., Li, Y., Shao, T., Zhang, H., Wang, Q., Qiao, J., 2014b. Quadrapyrgites from the lower Cambrian of South China: growth pattern, post-embryonic development, and affinity. Chinese Sci. Bull. 59, 4086-4095.

Liu, Y., Shao, T., Zhang, H., Wang, Q., Zhang, Y., Chen, C., Liang, Y., Xue, J., 2017. A new scyphozoan from the Cambrian Fortunian Stage of South China. Palaeontology $60,511-518$.

Liu, Y., Wang, Q., Shao, T., Zhang, H., Qin, J., Chen, L., Liang, Y., Chen, C., Xue, J., Liu, X., 2018. New material of three-dimensionally phosphatized and microscopic cycloneuralians from the Cambrian Paibian Stage of South China. J. Paleontol. 92, 87-98.

Lyons, T.W., Reinhard, C.T., Planavsky, N.J., 2014. The rise of oxygen in Earth's early ocean and atmosphere. Nature 506, 307.
Maas, A., Braun, A., Dong, X., Donoghue, P.C., Müller, K.J., Olempska, E., Repetski, J.E., Siveter, D.J., Stein, M., Waloszek, D., 2006. The 'Orsten'-more than a Cambrian Konservat-Lagerstätte yielding exceptional preservation. Palaeoworld 15, 266-282.

Maas, A., Mayer, G., Kristensen, R.M., Waloszek, D., 2007. A Cambrian micro-lobopodian and the evolution of arthropod locomotion and reproduction. Chinese Sci. Bull. 52, 3385-3392.

Maeda, H., Tanaka, G., Shimobayashi, N., Ohno, T., Matsuoka, H., 2011. Cambrian Orsten Lagerstatte from the Alum Shale Formation: Fecal pellets as a probable source of phosphorus preservation. Palaios 26, 225-231.

Maloof, A.C., Porter, S.M., Moore, J.L., Dudás, F.Ö., Bowring, S.A., Higgins, J.A., Fike, D.A., Eddy, M.P., 2010. The earliest Cambrian record of animals and ocean geochemical change. Bulletin 122, 1731-1774.

Manukyan, L., Montandon, S.A., Fofonjka, A., Smirnov, S., Milinkovitch, M.C., 2017. A living mesoscopic cellular automaton made of skin scales. Nature 544, 173-179.

Müller, K.J., Hinz-Schallreuter, I., 1993. Palaeoscolecid worms from the middle Cambrian of Australia. Palaeontology 36, 549-592.

Müller, K.J., Walossek, D., 1985. A remarkable arthropod fauna from the Upper Cambrian "Orsten" of Sweden. Trans. Royal Soc. Edinburgh 76, 161-172.

Murdock, D.J., Gabbott, S.E., Mayer, G., Purnell, M.A., 2014. Decay of velvet worms (Onychophora), and bias in the fossil record of lobopodians. BMC Evol. Biol. 14, 222

Neville, A.C., 2012. Biology of the arthropod cuticle (Vol. 4). Springer Science \& Business Media.

Parkhaev, P.Y., 2006. New data on the morphology of ancient gastropods of the genus Aldanella Vostokova, 1962 (Archaeobranchia, Pelagielliformes). Paleontol. J+ 40, 244-252.

Parkhaev, P.Y., 2014. Protoconch morphology and peculiarities of the early ontogeny of the Cambrian helcionelloid mollusks. Paleontol. J 48, 369-379.

Parry, L.A., Boggiani, P.C., Condon, D.J., Garwood, R.J., Leme, J.D.M., McIlroy, D., Brasier, M.D., Trindade, R., Campanha, G.A.C., Pacheco, M.L.A.F., Diniz, C.Q.C., Liu, A.G., 2017. Ichnological evidence for meiofaunal bilaterians from the terminal Ediacaran and earliest Cambrian of Brazil. Nat. Ecol. Evol. 1, 1455-1464.

Paterson, J.R., García-Bellido, D.C., Lee, M.S., Brock, G.A., Jago, J.B., Edgecombe, G.D., 2011. Acute vision in the giant Cambrian predator Anomalocaris and the origin of compound eyes. Nature 480, 237.

Paterson, J.R., García-Bellido, D.C., Jago, J.B., Gehling, J.G., Lee, M.S., Edgecombe, G.D. 2016. The Emu Bay Shale Konservat-Lagerstätte: a view of Cambrian life from East Gondwana. J. Geol. Soc. London 173, 1-11.

Peng, S., Babcock, L.E., Cooper, R.A., 2012. The Cambrian Period. The Geologic Time Scale 2, 437-488.

Pérez-de la Fuente, R., Delclòs, X., Peñalver, E., Speranza, M., Wierzchos, J., Ascaso, C., Engel, M.S., 2012. Early evolution and ecology of camouflage in insects. PNAS 109, 21414-21419.

Rota-Stabelli, O., Daley, A.C., Pisani, D., 2013. Molecular timetrees reveal a Cambrian colonization of land and a new scenario for ecdysozoan evolution. Curr. Biol. 23, 392-398.

Sahoo, S.K., Planavsky, N.J., Jiang, G.Q., Kendall, B., Owens, J.D., Wang, X., Shi, X.Y., Anbar, A.D., Lyons, T.W., 2016. Oceanic oxygenation events in the anoxic Ediacaran ocean. Geobiology 14, 457-468.

Schiffbauer, J.D., Wallace, A.F., Broce, J., Xiao, S., 2014. Exceptional fossil conservation through phosphatization. In: Laflamme, M., Schiffbauer, J.D., Darroch, S.A.F. (Eds.), Reading and Writing of the Fossil Record: Preservational Pathways to Exceptional Fossilization. The Paleontological Society Short Course, October 18 2014. pp. 59-82.

Schmalfuss, H., 1978. Structure, patterns, and function of cuticular terraces in recent and fossil arthropods. Zoomorphologie 90, 19-40.

Schmalfuss, H., 1981. Structure, patterns and function of cuticular terraces in trilobites. Lethaia 14, 331-341.

Shao, T., Liu, Y., Wang, Q., Zhang, H., Tang, H., Li, Y., 2016. New material of the oldest known scalidophoran animal Eopriapulites sphinx. Palaeoworld 25, 1-11.

Shao, T., Liu, Y., Duan, B., Zhang, H., Zhang, H., Wang, Q., Zhang, Y., Qin, J., 2018 The Fortunian (lowermost Cambrian) Qinscyphus necopinus (Cnidaria, Scyphozoa, Coronatae) underwent direct development. Neues Jahrb Geol P-A 289, 149-159.

Shao, T., Qin, J., Shao, Y., Liu, Y., Waloszek, D., Maas, A., Duan, B., Wang, Q., Xu, Y., Zhang, $\quad$ H., $2019 . \quad$ New 
macrobenthic cycloneuralians from the Fortunian (lowermost Cambrian) of South China. Precambr. Res. 105413.

Skovsted, C.B., Clausen, S., Álvaro, J.J., Ponleve, D., 2014. Tommotiids from the early Cambrian (Series 2, Stage 3) of Morocco and the evolution of the tannuolinid scleritome and setigerous shell structures in stem group brachiopods. Palaeontology 57, 171-192.

Stankiewicz, B.A., Briggs, D.E.G., 2001. Animal cuticles. Palaeobiology II 259-261.

Steiner, M., Zhu, M., Li, G., Qian, Y., Erdtmann, B.D., 2004. New Early Cambrian bilaterian embryos and larvae from China. Geology 32, 833-836.

Steiner, M., Li, G., Qian, Y., Zhu, M., Erdtmann, B.D., 2007. Neoproterozoic to early Cambrian small shelly fossil assemblages and a revised biostratigraphic correlation of the Yangtze Platform (China). Palaeogeogr., Palaeoclimat., Palaeoecol. 254, 67-99.

Steiner, M., Qian, Y., Li, G., Hagadorn, J.W., Zhu, M., 2014. The developmental cycles of early Cambrian Olivooidae fam. nov. (? Cycloneuralia) from the Yangtze Platform (China). Palaeogeogr., Palaeoclimat., Palaeoecol. 398, 97-124.

Steiner, M., Yang, B., Hohl, S., Zhang, L., Chang, S., 2020. Cambrian small skeletal fossil and carbon isotope records of the southern Huangling Anticline, Hubei (China) and implications for chemostratigraphy of the Yangtze Platform. Palaeogeogr., Palaeoclimat., Palaeoecol 109817 https://doi.org/10.1016/j.palaeo.2020.109817.

Su, W., Li, H., Warren, D.H., Ettensohn, F.R., Zhang, S., Zhou, H., Wan, Y., 2010. Zircon SHRIMP U-Pb ages of tuff in the Tieling Formation and their geological significance. Chinese Sci. Bull. 55, 3312-3323.

Tang, C., 2002. Orsten deposits from Sweden: Miniature late Cambrian arthropods. In: Bottjer, D.J., Etter, W., Tang, C., Hagadorn, J.W. (Eds.), Exceptional Fossil Preservation: A Unique View on the Evolution of Marine Life. Columbia University Press, New York, pp. 117-130.

Walossek, D.M., 1998. Cambrian 'Orsten'-type arthropods and the phylogeny of Crustacea. In: Arthropod Relationships. Springer, Dordrecht, pp. 139-153.

Walossek, D., 1999. On the Cambrian diversity of Crustacea. Crustaceans and the Biodiversity Crisis 1, 3-27.

Waloszek, D., 2003. The 'Orsten' window-a three-dimensionally preserved Upper Cambrian meiofauna and its contribution to our understanding of the evolution of Arthropoda. Paleontol. Res. 7, 71-88.

Wang, J., Li, Z., 2003. History of Neoproterozoic rift basins in South China: implications for Rodinia break-up. Precambr. Res. 122, 141-158.

Wang, D., Vannier, J., Schumann, I., Wang, X., Yang, X., Komiya, T., Uesugi, K., Sun, J., Han, J., 2019. Origin of ecdysis: fossil evidence from 535-million-year-old scalidophoran worms. P. Roy. Soc. B-Biological Sciences 286, 20190791.

Wang, D., Vannier, J., Yang, X., Sun, J., Sun, Y., Hao, W., Tang, Q., Liu, P., Han, J., 2020. Cuticular reticulation replicates the pattern of epidermal cells in lowermost Cambrian scalidophoran worms. P. Roy. Soc. B-Biological Sciences 287, 20200470.

Waugh, D.A., Feldmann, R.M., Burrell, J.L., Hull, A.L., Hein, K., Schweitzer, C.E., 2009. Ontogenetic variations in cuticle morphology in the blue crab Callinectes sapidus Rathbun, 1896. J. Crustacean Biol. 29, 141-156.

Wen, R., Zhao, Y., Peng, J., 2015. Morphology and ontogeny of Tuzoia bispinosa from the Kaili Biota (Cambrian Stage 5) of eastern Guizhou, China. Palaeoworld 24, 61-70.

Wood, R., Ivantsov, A.Y., Zhuravlev, A.Y., 2017. First macrobiota biomineralization was environmentally triggered. Proc. R. Soc. B 284, 20170059.

Wray, G.A., 2015. Molecular clocks and the early evolution of metazoan nervous systems. Phil. Trans. R. Soc. Lond. B 370, 20150046.

Xiao, S.H., Knoll, A.H., 1999. Fossil preservation in the Neoproterozoic Doushantuo phosphorite Lagerstätte. South China. Lethaia 32, 219-240.

Xiao, S.H., Zhou, C.M., Liu, P.J., Wang, D., Yuan, X.L., 2014. Phosphatized acanthomorphic acritarchs and related microfossils from the Ediacaran Doushantuo Formation at Weng'an (South China) and their implications for biostratigraphic correlation. J. Paleontol. 88, 1-67. doi:10.1666/12-157R.

Xiao, S.H., Chen, Z., Zhou, C.M., Yuan, X.L., 2019. Surfing in and on microbial mats: Oxygen-related behavior of a terminal Ediacaran bilaterian animal. Geology 47, 1054-1058.
Yang, D., Sun, S. (Eds.), 2006. Marine Invertebrate Zoology. China Ocean University Press, Qingdao.

Yang, J., Ortega-Hernández, J., Drage, H.B., Du, K., Zhang, X., 2019. Ecdysis in a stem-group euarthropod from the early Cambrian of China. Sci. Rep. 9, 1-9.

Yin, C., Gao, L., 1995. The early evolution of the acanthomorphic acritarchs in China and their biostratigraphical implication. Acta Geol. Sin. 69, 360-370 (in Chinese).

Yin, Z., Zhu, M., 2012. New observations of the ornamented Doushantuo embryo fossils from the Ediacaran Weng'an Biota, South China. B. Geosci. 87, 171-181.

Yin, Z., Zhu, M., Davidson, E.H., Bottjer, D.J., Zhao, F., Tafforeau, P., 2015. Sponge grade body fossil with cellular resolution dating 60 Myr before the Cambrian. PNAS 112, 1453-1460.

Yin, Z., Zhu, M., Bottjer, D.J., Zhao, F., Tafforeau, P., 2016. Meroblastic cleavage identifies some Ediacaran Doushantuo (China) embryo-like fossils as metazoans. Geology 44, 735-738.

Yin, Z., Zhao, D., Pan, B., Zhao, F., Zeng, H., Li, G., Bottjer, D.J., Zhu, M., 2018. Early Cambrian animal diapause embryos revealed by X-ray tomography. Geology 46, 387-390.

Yin, Z., Vargas, K., Cunningham, J., Bengtson, S., Zhu, M., Marone, F., Donoghue, P., 2019. The early Ediacaran Caveasphaera foreshadows the evolutionary origin of animal-like embryology. Curr. Biol. 29 (24), 4307-4314.

Yue, Z., Bengtson, S., 1999. Embryonic and post-embryonic development of the Early Cambrian cnidarian Olivooides. Lethaia 32, 181-195.

Zhang, X., 1987. Moult stages and dimorphism of Early Cambrian bradoriids from Xichuan, Henan, China. Alcheringa 11, 1-19.

Zhang, X., 2007. Phosphatized bradoriids (Arthropoda) from the Cambrian of China. Palaeontogr. Abt. A. 93-173.

Zhang, X., Pratt, B.R., 1994. Middle Cambrian arthropod embryos with blastomeres. Science 266, 637-639.

Zhang, X., Pratt, B.R., 1996. Early Cambrian palaeoscolecid cuticles from Shaanxi, China. J. Paleontol. 70, 275-279.

Zhang, X., Pratt, B.R., 2012. The first stalk-eyed phosphatocopine crustacean from the Lower Cambrian of China. Curr. Biol. 22, 2149-2154.

Zhang, X., Siveter, D.J., Waloszek, D., Maas, A., 2007. An epipodite-bearing crown-group crustacean from the Lower Cambrian. Nature 449, 595.

Zhang, X., Maas, A., Haug, J.T., Siveter, D.J., Waloszek, D., 2010. A eucrustacean metanauplius from the Lower Cambrian. Curr. Biol. 20, 1075-1079.

Zhang, X., Shu, D., Han, J., Zhang, Z., Liu, J., Fu, D., 2014. Triggers for the Cambrian explosion: hypotheses and problems. Gondwana Res. 25, 896-909.

Zhang, H., Xiao, S., Liu, Y., Yuan, X., Wan, B., Muscente, A.D., Shao, T., Gong, H., Cao, G., 2015. Armored kinorhynch-like scalidophoran animals from the early Cambrian. Sci. Rep. 5, 16521.

Zhang, X., Smith, M.R., Yang, J., Hou, J., 2016a. Onychophoran-like musculature in a phosphatized Cambrian lobopodian. Biol. letters 12, 20160492.

Zhang, Z., Zhang, Z.F., Wang, H., 2016b. Epithelial cell moulds preserved in the earliest acrotretid brachiopods from the Cambrian (Series 2) of the Three Gorges area, China. GFF 138, 455-466.

Zhang, J., Fan, T., Zhang, Y., Lash, G., Li, Y., Wu, Y., 2017. Heterogenous oceanic redox conditions through the Ediacaran-Cambrian boundary limited the metazoan zonation. Sci. Rep. 7, 1-9.

Zhang, F., Xiao, S., Kendall, B., Romaniello, S.J., Cui, H., Meyer, M., Gilleaudeau, G.J., Kaufman, A.J., Anbar, A.D., 2018a. Extensive marine anoxia during the terminal Ediacaran Period. Sci. Adv. 4, eaan8983.

Zhang, L., Chang, S., Khan, M.Z., Feng, Q., Danelian, T., Clausen, S., Tribovillard, N., Steiner, M., 2018b. The link between metazoan diversity and paleo-oxygenation in the early Cambrian: An integrated palaeontological and geochemical record from the eastern Three Gorges Region of South China. Palaeogeogr., Palaeoclimat., Palaeoecol 495, 24-41.

Zhang, Z., Skovsted, C.B., Zhang, Z., 2018c. A hyolithid without helens preserving the oldest hyolith muscle scars; palaeobiology of Paramicrocornus from the Shujingtuo Formation (Cambrian Series 2) of South China. Palaeogeogr., Palaeoclimat., Palaeoecol. 489, 1-14.

Zhang, L., Chang, S., Khan, M.Z., Feng, Q., Luo, C., Steiner, M., Forel, M.B., Liu, K. Clausen, S., 2020. Influence of palaeo-redox and diagenetic conditions on the spatial distribution 
of Cambrian biotas: A case study from the upper Shuijingtuo Formation (Cambrian Series 2, Stage 3), Three Gorges area of South China. Palaeogeogr., Palaeoclimat. Palaeoecol. 109696. 